\title{
nam \\ Production of Jet Biofuels by Catalytic Hydroprocessing of Esters and Fatty Acids: A Review
}

\author{
Rodolpho R. C. Monteiro ${ }^{1}$ (D) Isabela A. dos Santos ${ }^{1}$, Maria R. A. Arcanjo ${ }^{1}$, Célio L. Cavalcante, Jr. ${ }^{1}$ (i), \\ Francisco M. T. de Luna ${ }^{1}\left(\mathbb{D}\right.$, Roberto Fernandez-Lafuente ${ }^{2,3, * \mathbb{C}}$ and Rodrigo S. Vieira ${ }^{1, *}$ \\ 1 Grupo de Pesquisa em Separações por Adsorção (GPSA), Departamento de Engenharia Química, \\ Campus do Pici, Universidade Federal do Ceará, Fortaleza 60455760, Brazil; \\ rodolpho.monteiro@gpsa.ufc.br (R.R.C.M.); isabela.santos@gpsa.ufc.br (I.A.d.S.); \\ rosi.arcanjo@gpsa.ufc.br (M.R.A.A.); celio@gpsa.ufc.br (C.L.C.J.); murilo@gpsa.ufc.br (F.M.T.d.L.) \\ 2 Departamento de Biocatálisis, ICP-CSIC, Campus UAM-CSIC, 28049 Madrid, Spain \\ 3 Center of Excellence in Bionanoscience Research, External Scientific Advisory Academics, \\ King Abdulaziz University, Jeddah 21589, Saudi Arabia \\ * Correspondence: rfl@icp.csic.es (R.F.-L.); rodrigo@gpsa.ufc.br (R.S.V.)
}

\section{check for}

updates

Citation: Monteiro, R.R.C.; dos Santos, I.A.; Arcanjo, M.R.A.;

Cavalcante, C.L., Jr.; de Luna, F.M.T.; Fernandez-Lafuente, R.; Vieira, R.S. Production of Jet Biofuels by Catalytic Hydroprocessing of Esters and Fatty Acids: A Review. Catalysts 2022, 12, 237. https://doi.org/ $10.3390 /$ catal12020237

Academic Editors: Vincenzo Vaiano and Olga Sacco

Received: 21 January 2022

Accepted: 18 February 2022

Published: 20 February 2022

Publisher's Note: MDPI stays neutral with regard to jurisdictional claims in published maps and institutional affiliations.

Copyright: (C) 2022 by the authors. Licensee MDPI, Basel, Switzerland. This article is an open access article distributed under the terms and conditions of the Creative Commons Attribution (CC BY) license (https:// creativecommons.org/licenses/by/ $4.0 /)$.

\begin{abstract}
The transition from fossil to bio-based fuels is a requisite for reducing $\mathrm{CO}_{2}$ emissions in the aviation sector. Jet biofuels are alternative aviation fuels with similar chemical composition and performance of fossil jet fuels. In this context, the Hydroprocessing of Esters and Fatty Acids (HEFA) presents the most consolidated pathway for producing jet biofuels. The process for converting esters and/or fatty acids into hydrocarbons may involve hydrodeoxygenation, hydrocracking and hydroisomerization, depending on the chemical composition of the selected feedstock and the desired fuel properties. Furthermore, the HEFA process is usually performed under high $\mathrm{H}_{2}$ pressures and temperatures, with reactions mediated by a heterogeneous catalyst. In this framework, supported noble metals have been preferably employed in the HEFA process; however, some efforts were reported to utilize non-noble metals, achieving a similar performance of noble metals. Besides the metallic site, the acidic site of the catalyst is crucial for product selectivity. Bifunctional catalysts have been employed for the complete process of jet biofuel production with standardized properties, with a special remark for using zeolites as support. The proper design of heterogeneous catalysts may also reduce the consumption of hydrogen. Finally, the potential of enzymes as catalysts for intermediate products of the HEFA pathway is highlighted.
\end{abstract}

Keywords: jet biofuel; biokerosene; hydroprocessing of esters and fatty acids; HEFA; heterogeneous catalysis; chemical catalysis; biocatalysis

\section{Introduction}

The global energy demand for 2020 was estimated to reduce by $6 \%$ compared to the previous year [1]; however, the total energy demand is supposed to return to the level of pre-crisis of the COVID-19 pandemic by early 2023 [2]. Notwithstanding, for 2020, the Global Energy Report from the International Energy Agency expected the demand for renewable energy to increase due to its low operating costs and priority dispatch; moreover, the recent growth in generation capacity and a number of new projects would possibly increase the output as well [1]. During 2020, a 10.3\% (261 GW) growth in generation capacity for renewable energy worldwide was reported [3]. Therefore, apart from the COVID-19 pandemic crisis, the renewable energy demand is projected to accelerate significantly; indeed, the participation of renewable energy in total final energy consumption worldwide is expected to increase from $19 \%$ in 2017 to approximately $66 \%$ by 2050 [4]. Utilizing renewable energy is an imperative requirement for the transition of the fossil-based energy matrix to zero-carbon global emissions in the energy sector. The World Energy Transitions Outlook has reported six main components for $\mathrm{CO}_{2}$ emission reduction: renewable energy; 
energy conservation and efficiency; electrification in the end-use sectors; hydrogen and its derivatives such as e-ammonia and e-methanol; carbon capture, storage and utilization; and bioenergy coupled with carbon capture and storage [5]. Among these components to reduce $\mathrm{CO}_{2}$ emissions, renewable fuels and biomass-based carbon removal technologies play a key role in the decarbonization efforts [5].

In particular, the global demand for energy in the transportation sector continues to increase and, for instance, transportation energy demand is expected to increase by 77\% from 2018 to 2050 in regions outside the Organization for Economic Cooperation and Development (OECD) [6]. Thus, although the global transportation emissions increased by less than $0.5 \%$ in 2019 , it still accounts for $24 \%$ of the direct emissions of $\mathrm{CO}_{2}$ from combustion of fuels [7].

The $\mathrm{CO}_{2}$ emissions from the aviation sector have quickly risen over the last two decades, accounting for approximately $2.8 \%$ of the global $\mathrm{CO}_{2}$ emissions from fossil fuel combustion [8]. Nonetheless, the International Civil Aviation Organization (ICAO) has established goals to reach neutral carbon growth from 2020 onward and reduce $\mathrm{CO}_{2}$ emissions to half of the 2005 levels by 2050 [9]. ICAO has implemented the Carbon Offsetting and Reduction Scheme for International Aviation (CORSIA) to compensate for any increment in the emissions of $\mathrm{CO}_{2}$ in the atmosphere above the 2020 level. The ICAO has agreed to modify the CORSIA baseline to reflect only 2019 levels due to the impact of the COVID-19 pandemics on aviation in 2020 [10]. Therefore, the transition from fossil fuels to biofuels is imperative in the aviation sector for reducing $\mathrm{CO}_{2}$ emissions; indeed, implementation of alternative fuels in the aviation sector could potentially decrease $\mathrm{CO}_{2}$ emissions by up to $68.1 \%$ in 2050 [11]. Unfortunately, despite some recent progress in policy support [12-16], the demand for biofuels in the aviation sector represented less than $0.01 \%$ of the total demand for fuel in the sector in 2018, when the Sustainable Development Scenario from the International Energy Agency required this value to be $9 \%$ of the aviation fuel demand by 2030 [17].

Beyond the mitigation of $\mathrm{CO}_{2}$ emissions in the atmosphere, the implementation of biofuels in the aviation sector may potentially diversify and/or complement the energy matrix to reduce the dependence on fossil fuels, for which prices are constantly fluctuating; therefore, biofuels may ensure security and energy independence [18,19]. Furthermore, the utilization of biofuels may also be associated with social and economic development [20].

By definition, jet biofuels, also known as biokerosene, are biofuels or alternative aviation fuels obtained from renewable sources. They are hydrocarbons produced from renewable resources, also coined as biohydrocarbons, with the same boiling range of fossil jet fuels. Therefore, jet biofuels must share a similar chemical composition and high energy density with current fossil jet fuels [21-23]. Moreover, jet biofuels must be tailored for aircraft engines; thereby, jet biofuels must hold very similar or even identical fuel properties and performance of fossil jet fuels to be used as drop-in biofuels [24]. Different pathways may produce jet biofuels, depending on the renewable feedstock used, with the chosen path influencing the composition, properties, cost, availability and environmental impact of the biofuel $[22,25,26]$. Currently, there are eight conversion pathways for the production of jet biofuels, according to the American Society for Testing and Materials (ASTM, for short; designations D7566-20a and D1655-20c) [27,28].

Therefore, the implementation of biofuels in the aviation sector must meet the criteria for sustainability under the environmental, economic and social perspectives; in fact, ICAO has recognized the need for biofuels to be developed and deployed in a manner that is economically viable and socially and environmentally acceptable. That said, it is imperative to implement jet biofuels in the aviation sector, as reflected in the increasing number of patents [21] and papers on this subject (Figure 1). Jet biofuels have been addressed in the last ten years by several authors. For instance, the production pathways for jet biofuels were reported by Hari et al. (2015) [22], Wang and Tao (2016) [29], Gutiérrez-Antonio et al. (2017) [21], Karatzos et al. (2017) [30] and Wei et al. (2019) [31]. Furthermore, the utilization of microalgae oil [32], lignin [33], waste cooking oil [34] and fish discards [35] 
and the respective pathways for producing jet biofuels were also reported. Furthermore, the production processes of jet biofuels from triacylglycerols have been extensively studied [36-40]. In this communication, the catalytic mechanisms of the hydroprocessing of esters and fatty acids (hydrogenation, decarboxylation, decarbonylation, cracking and isomerization) are reviewed, along with the employed catalysts. Additionally, attempts to reduce the consumption of exogenous $\mathrm{H}_{2}$ are highlighted as well as the employment of enzymes as catalysts to obtain jet biofuels intermediates.

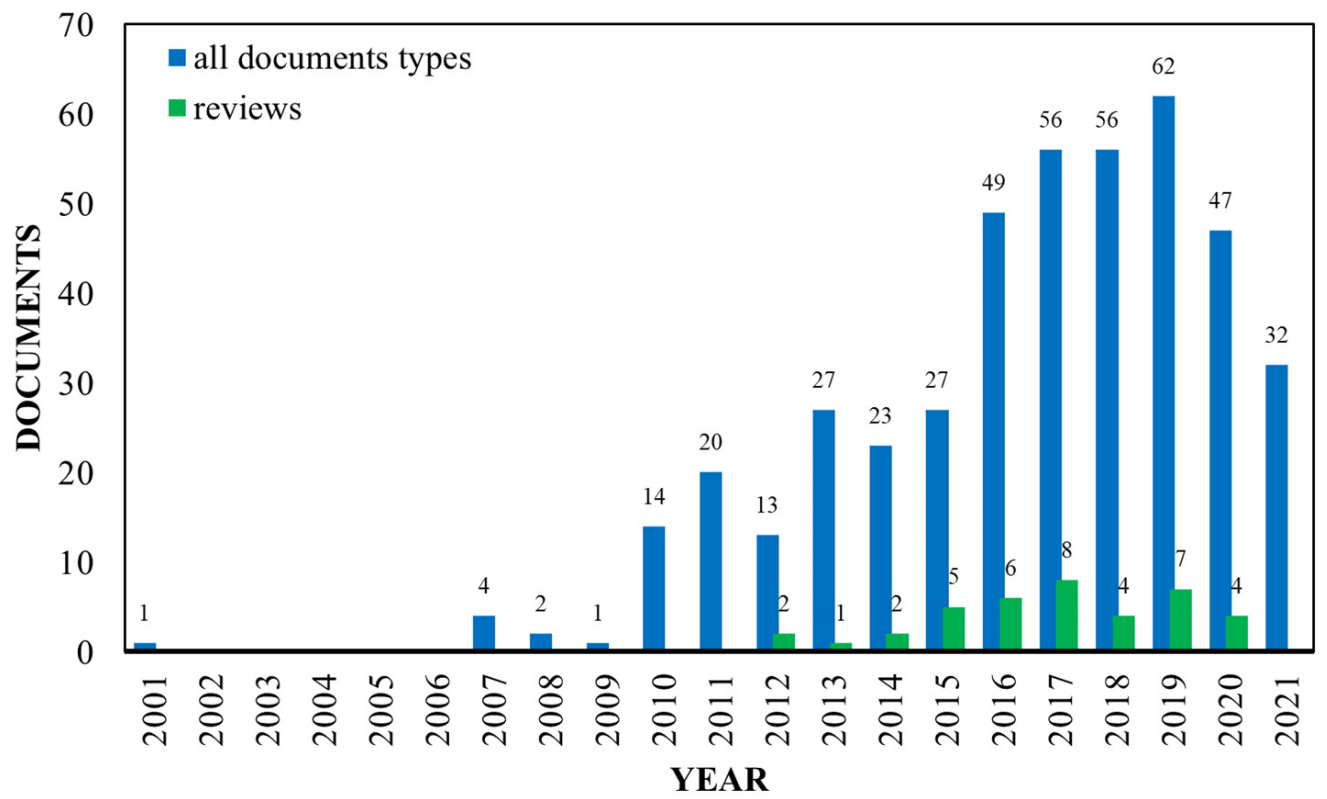

Figure 1. Bibliometric trends for jet biofuel research. Search algorithms on Scopus: (TITLE-ABS-KEY (biojet AND fuel) OR TITLE-ABS-KEY (bio-jet AND fuel) OR TITLE-ABS-KEY (biokerosene)) and (TITLE-ABS-KEY (biojet AND fuel) OR TITLE-ABS-KEY (bio-jet AND fuel) OR TITLE-ABS-KEY (biokerosene)) AND (LIMIT-TO (DOCTYPE "re")). According to the authors bibliographic research, biojet fuel is the term most commonly used to refer bio-based alternative aviation fuels, however, here we proposed to use jet biofuel instead of biojet fuel.

\section{Catalytic Hydroprocessing of Esters and Fatty Acids (HEFA)}

The HEFA process represents the most consolidated pathway among the approved and certified processes by the American Society for Testing and Materials (ASTM) for producing alternative aviation fuels. The production of jet biofuels via the HEFA process is illustrated in Figure 2. The HEFA process offers potential for large-scale short-term production [15,41,42]. Compared to other processes, it exhibits lower technological complexity [15,41], and a lower minimum jet biofuel selling price [43], with higher energy efficiency [44]. Hydrotreatment processes of petroleum streams is already a well-established technology for the removal of sulfur (hydrodesulfurization), nitrogen (hydrodenitrogenation) and oxygen (hydrodeoxygenation), as well as for the saturation of olefins and aromatics $[45,46]$. Therefore, the hydroprocessing of esters and fatty acids for jet biofuel production may be performed at existing refineries, thereby reducing capital costs. Some airlines have employed jet biofuels produced via the HEFA process for demonstration and even in some commercial flights [21].

The HEFA process converts acylglycerols (esters) and fatty acids into hydrocarbons to produce jet biofuels, in the presence of $\mathrm{H}_{2}$, for removal of the oxygen atom from the feedstock [34]. Chemically, hydroprocessed jet biofuels are generally paraffinic liquids, free of aromatics and sulfur, with a carbon chain length of $C_{8}-C_{16}$ [22]. This chemical composition is imperative for their performance behavior [47]. The high paraffinic content in hydroprocessed jet biofuels may result in good thermal stability, which may be even better than fossil jet fuels, since paraffins exhibit a weak tendency to form deposits in 
engine fuel systems at higher temperatures; moreover, it may reduce emissions of soot, particulate matter, $\mathrm{CO}$ and unburned hydrocarbons [47]. Nevertheless, the presence of iso-paraffins and/or aromatics may be necessary to yield lower freezing points, higher oxidative stabilities and higher cetane numbers; moreover, the presence of aromatics is necessary for jet biofuels with higher densities at $-15{ }^{\circ} \mathrm{C}$ and for the volume swell of the sealing materials in the aircraft system [47]. Furthermore, the carbon chain length may influence the jet biofuel's low-temperature fluidity (kinematic viscosity at $-20{ }^{\circ} \mathrm{C}$ ) and volatility, whereas the absence of sulfur, oxygen, and nitrogen may result in poor lubricity [47].

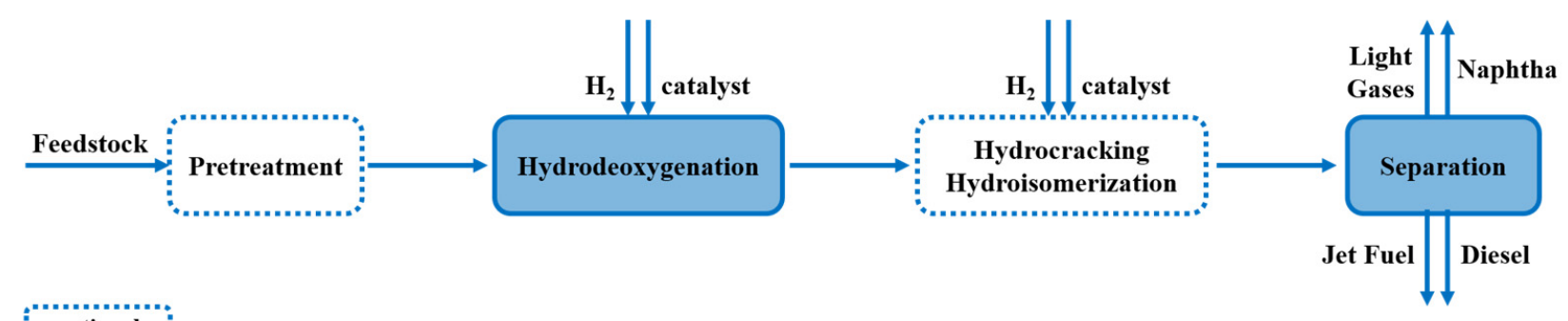

Figure 2. Simplified Hydroprocessing of Esters and Fatty Acids (HEFA) for jet biofuel production. Adapted from [41].

Several studies exemplified the use of renewable feedstocks for the production of jet biofuels [36-40]. Overall, it was reported that soybean, which is a widely employed crop for the production of oil, bears relatively low oil yield when compared to palm, coconut and jatropha, for example. However, some oil crops may not be suitable for jet biofuel production due to food security and, therefore, lower-price animal fats and greases may be employed in the HEFA pathway [48]. In the Brazilian scenario, soybean crops should provide the most feasible oil source for the production of jet biofuel due to its lower cost and high agricultural maturity; however, soybean oil is the main feedstock used for the production of biodiesel in Brazil, thus other potential crops must be evaluated [49]. In any case, as feedstocks, for instance, vegetable oils, animal fats, algal oils, and bio-oils may be used for jet biofuel production by the HEFA process [21,49]; and, depending on the feedstock quality, a pretreatment (filtration for removal of impurities and heating for moisture removal) may be necessary [34]. The choice of feedstock is crucial as it may result in a jet biofuel with the same carbon chain length or one atom less than the corresponding fatty acids of the feedstock [50]; therefore, the use of feedstocks composed mainly of fatty acids with carbon chain lengths in the range of jet fuel may avoid the cracking and/or distillation step. Furthermore, the use of highly unsaturated feedstock may require the saturation of the double bonds of the correspondent fatty acid, thus increasing $\mathrm{H}_{2}$ consumption. In this sense, in addition to removing oxygen from the feedstock through hydrodeoxygenation, the HEFA process may include the hydrocracking and hydroisomerization of the feedstock, aiming to fulfill the standards for alternative aviation fuels addressed by ASTM, as well as the distillation of the product for hydrocarbon separation $[47,51]$. As a matter of fact, if the ASTM specifications are met, hydroprocessed jet biofuels may be used as drop-in biofuels, even without blending, since they are suitable for conventional aircraft engines without further engine modification [22].

In the HEFA pathway, the design of the heterogeneous catalytic system is a crucial step, especially regarding product selectivity and no coke formation, although non-catalytic hydroprocessing may also be applied. Heterogeneous catalytic systems involve several advantages compared to homogeneous systems, such as the possibility of recovery and regeneration of the catalyst, the minimization of purification steps, non-hazardous and more ecological process [40]. In addition, such catalytic systems may prove more resistant to adverse operating conditions that may eventually destroy homogeneous catalyst materi- 
als [40]. However, the activity of the heterogeneous catalyst must be equivalent, or at least close, to that of its homogeneous counterpart. A key parameter is the number of use cycles (or on-stream time in continuous reactors), which relates to the stability of the catalyst [52]. Therefore, incorporating heterogeneous catalysts in catalytic processes may be an attempt to mitigate the challenges encountered with their homogeneous counterparts.

\subsection{Catalytic Hydrodeoxygenation}

Oils and fats are mainly composed of acylglycerols and fatty acids; therefore, such feedstocks may contain a high oxygen content from the glycerol backbone and the acyl portion of the molecules, although it may be lower than that of bio-oils derived from lignocellulosic feedstocks. The average oxygen content of bio-oils may reach up to threefold higher than that of oils and fats [53]. High oxygen content in feedstocks used for biofuel production may lead to immiscibility with fossil fuels and higher viscosity, restricting their use for blends and worsening the cold flow properties, respectively. Moreover, high oxygen content may result in very reactive and unstable biofuels, increasing the tendency of polymerization, eventual gum and sludge formation, and decreasing their thermal and storage stabilities [54].

Biodiesel was proposed to be blended with aviation fuels [55-58]; however, biodiesel is generally produced by the transesterification of acylglycerols-or by the esterification of free fatty acids-with short-chain alcohols (ethyl alcohol or methyl alcohol, for example), resulting in esters with high oxygen content [59]. Therefore, the use of biodiesel as a drop-in jet biofuel or even blended with fossil or bio-based fuels for aviation is not recommended, and should be limited to less than 5 ppm, according to ASTM D7566 [27]. For instance, Fatty Acid Methyl Esters (FAMEs) were obtained by the transesterification of methyl alcohol with oils from macaúba (Acrocomia aculeate) and palm (Elaeis guineensis) fruit kernel; further, the FAMEs were fractionated through atmospheric distillation to obtain short-chain esters $\left(\mathrm{C}_{8}-\mathrm{C}_{14}\right)$ aiming to blend them with fossil jet fuel; as a result, the blend (5 vol.\%) of the light biodiesel cut $\left(\mathrm{C}_{12}\right)$ with the fossil jet fuel met the main technical standard properties (moisture content, density, distillation and flash point) [60].

Oils and fats must be deoxygenated to meet the ASTM's standards for alternative aviation fuels. In this sense, hydrodeoxygenation is a catalytic hydrogenolysis process to eliminate oxygen heteroatoms from oils and fats, which is performed under high $\mathrm{H}_{2}$ pressures and temperatures [50]. The main purpose of the hydrodeoxygenation process is to decrease the $\mathrm{O} / \mathrm{C}$ ratio and concomitantly increase the $\mathrm{H} / \mathrm{C}$ ratio and saturate the double bonds of the oils and fats, producing biohydrocarbons with a similar chemical composition of hydrocarbons [54]. Strictly, during the hydrodeoxygenation of oils and fats, three main reactions may take place (hydrogenation, decarboxylation and decarbonylation).

In the hydrogenation pathway, the double bonds of fatty acid chains are saturated by adding molecular hydrogen (e.g., $\mathrm{C}_{18} \mathrm{H}_{34} \mathrm{O}_{2}$ to $\mathrm{C}_{18} \mathrm{H}_{36} \mathrm{O}_{2}$, oleic acid being saturated to stearic acid with $\mathrm{H}_{2}$ ), without cleaving bonds (Figure 3a) [61]. Triacylglycerols hydrogenation may occur by three different decomposition pathways ( $\gamma$-hydrogen migration, $\beta$-elimination and direct deoxygenation) (see Figure 3b). The $\gamma$-hydrogen migration mechanism within the acyl group of the triacylglycerol chain yields monoalkenes [62]. The $\beta$-elimination mechanism releases one fatty acid from the triacylglycerol chain, which becomes an unsaturated diacylglycerol; subsequently, the released fatty acid may be deoxygenated to obtain paraffin or $\alpha$-olefins [62]. The direct deoxygenation mechanism of triacylglycerols is not precise yet; however, it is known to not involve the formation of intermediate fatty acids, albeit it may involve the formation of glycerol/propane [61].

In the decarboxylation pathway, the carboxyl group is removed from the triacylglycerol chain through a direct $\mathrm{C}-\mathrm{C}$ bond cleavage in the presence of $\mathrm{H}_{2}$, thus resulting in the production of linear alkanes containing an additional carbon atom in the chain length compared to the triacylglycerol chain [40]. Therefore, deoxygenation of the feedstock is achieved by eliminating $\mathrm{O}_{2}$ and releasing $\mathrm{CO}_{2}$ as a by-product of the decarboxylation mechanism (Figure 3c) [63]. In addition, it is reported that the decarboxylation pathway 
occurs through $\gamma$-hydrogen migration and $\beta$-elimination as well as the hydrogenation pathway [64]. Similarly, in the decarbonylation pathway, the carboxyl group is removed from the triacylglycerol chain through a direct $\mathrm{C}-\mathrm{C}$ bond cleavage in the presence of $\mathrm{H}_{2}$, also resulting in the production of linear alkanes with an additional carbon atom in the chain length [40]. However, the deoxygenation of the feedstock is achieved by eliminating $\mathrm{O}_{2}$ and releasing $\mathrm{CO}$ and $\mathrm{H}_{2} \mathrm{O}$ as a by-product of the decarboxylation mechanism (see Figure 3c) [65].

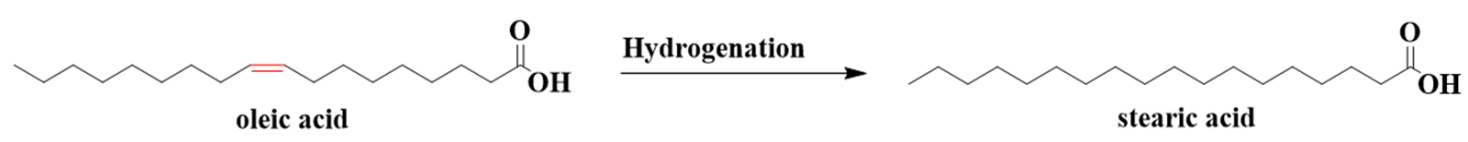

(a)<smiles>[R]CCC(=O)OCC(=C)OC(=O)CC[R]</smiles><smiles>[R]CCC(=O)OCC(=O)OCC(=O)OCC1CC1</smiles><smiles></smiles><smiles>CC1CC1C</smiles><smiles>[R]CCC(=O)OCC(CO)OC(=O)CC[R]</smiles><smiles>[R]CC(C)([OH2+])C(=O)O</smiles>

(b)

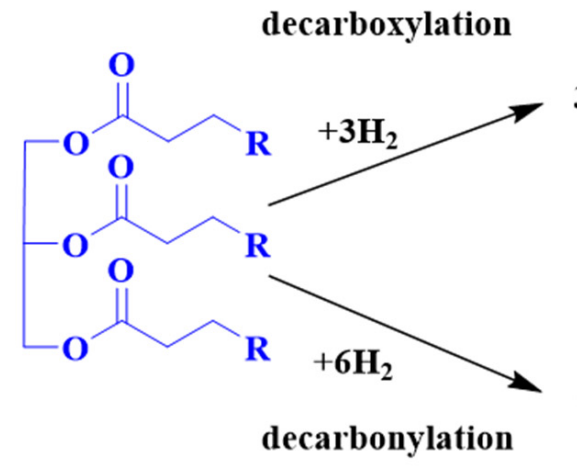

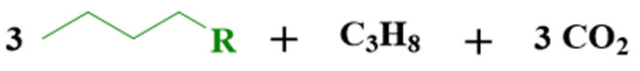<smiles>CCCC[Te]CC(=O)[O-]</smiles>

(c)

Figure 3. Hydrodeoxygenation of triacylglycerols through hydrogenation $(\mathbf{a}, \mathbf{b})$, decarboxylation and decarbonylation (c). 
The deoxygenation of triacylglycerols by hydrodeoxygenation consumes much more $\mathrm{H}_{2}$ than deoxygenation by decarboxylation and decarbonylation; it is even possible to deoxygenate triacylglycerols through decarboxylation/decarbonylation without using $\mathrm{H}_{2}$, which is consumed in these reactions [64]. Furthermore, although free fatty acids may be theoretically employed as feedstocks for producing jet biofuels via the HEFA process, in practice, only triacylglycerols (oils and fats) are used; therefore, this communication was focused on the reaction mechanisms underlying hydrodeoxygenation of triacylglycerols. The reaction mechanisms of hydrodeoxygenation of free fatty acids or model compounds were recently extensively reviewed $[61,62,64]$.

Supported metals are the most commonly employed catalysts for the hydrodeoxygenation reaction of triacylglycerols / fatty acids to obtain jet biofuels. Noble metals or transition metals may accelerate decarboxylation or decarbonylation of the feedstock by weakening the carboxyl or carbonyl group, respectively, while transition metal-oxides with moderate acidity facilitate deoxygenation by activating the hydroxyl group [66]. For instance, palladium (5 wt.\%), supported on charcoal (Pd/C), was employed in the hydrodeoxygenation of crude and hydrolyzed macaúba (Acrocomia aculeata) oils extracted from its pulp and almonds. As a result, the highest conversion $(85 \% w / w)$ to hydrocarbons was achieved for the hydrolyzed almond oil at 10 bar of $\mathrm{H}_{2}, 300{ }^{\circ} \mathrm{C}, 5 \mathrm{~h}$ and $700 \mathrm{rpm}$ [67]. The best catalytic performance was observed for the hydrolyzed feedstocks with a lower unsaturated content, since smaller carbon chains exhibit lower viscosity and higher diffusivity, which may facilitate the access of reagents to the catalytic sites. Furthermore, a high hydrogenation activity of $\mathrm{Pd} / \mathrm{C}$ was reported since all hydrocarbons formed were saturated [67]. Similarly, the $\mathrm{Pd} / \mathrm{C}$ catalyst was employed for the deoxygenation of licuri (Syagrus coronata) oil and biodiesel, showing conversion to $n$-alkanes of 39.2 mol.\% for licuri biodiesel at 207 psi of $\mathrm{He}\left(5 \%\right.$ of $\left.\mathrm{H}_{2}\right), 300{ }^{\circ} \mathrm{C}, 4 \mathrm{~h}$ and $1000 \mathrm{rpm}$ [68]. The decarboxylation pathway is preferred as the production of $n$-alkanes occurs with the loss of the carboxyl group from the feedstock, as well as the selectivity to $\mathrm{CO}_{2}$ being much higher than that to $\mathrm{CO}$. Moreover, it was reported that the increase in the number of carbon atoms in the feedstock chain enhances the catalytic deoxygenation process [68]. Overall, $\mathrm{Pd}$ was reported as an excellent catalyst for the formation of linear chain paraffin; however, its deactivation due to the poisoning of the active sites by adsorbed reaction intermediates (heavy organic substances, carbonaceous deposits and carbon monoxide, for example) and high cost renders it unfeasible for commercial use [69].

In addition to carbon-based supports, other supports have been used to prepare metal catalysts employed in the HEFA process. As an example, nickel (Ni) and molybdenum (Mo), supported on hierarchical USY-zeolite, were applied to the hydrodeoxygenation of waste cooking oil; remarkably, the dealumination treatment of the support was able to enhance the activity and selectivity of the catalyst. This may be explained by the better acid distribution and mass transfer properties of the dealuminated hierarchical structure [70]. In a similar study, Ni and Mo were supported on hierarchical USY@Al-SBA-15-zeolite and also evaluated at the hydrodeoxygenation reaction of waste cooking oil. Remarkably, the core-shell USY@Al-SBA-15 catalyst with hierarchical pores also significantly contributed to the improvement of the selectivity in the production of jet biofuels [71]. Thus, zeolite-based catalyst supports were reported to provide adequate characteristics for obtaining biofuels with properties very similar to those of fossil fuels, due to the possibility of their synthesis with different pore size ranges and shapes, besides allowing control of the concentration of acid functional groups on their surface [72].

In addition to $\mathrm{Pd}$ and $\mathrm{Ni}$, platinum $(\mathrm{Pt})$ represents another transition metal employed as a catalyst in the hydrodeoxygenation of feedstocks for jet biofuel production; indeed, $\mathrm{Pt}$ has been recognized as the most suitable metal for the production of paraffins [73-76]. $\mathrm{Pt}$, supported on $\mathrm{Al}_{2} \mathrm{O}_{3}$, was employed as a catalyst in the hydroprocessing of palm oil for paraffin production, with suitable Pt loading favoring the decarbonylation and decarboxylation pathways [77]. In the same study, another catalyst $\left(\mathrm{Ni}_{2} \mathrm{P} / \mathrm{SiO}_{2}\right)$ was mixed with $\mathrm{Pt} / \mathrm{Al}_{2} \mathrm{O}_{3}$, resulting in a more active and stable catalyst with an extremely low for- 
mation of carbon deposits and thus preserving the Brønsted acidity associated with the hydrodeoxygenation pathway [77]. The utilization of noble metals ( $\mathrm{Pd}, \mathrm{Pt}$ and $\mathrm{Ru}$ ) in the hydrodeoxygenation of feedstocks may increase the production costs of jet biofuels since such metals are extremely expensive; therefore, alternative non-noble metals have been sought, such as nickel (Ni), already reported above, and cobalt (Co). Co, supported on activated carbon obtained from the macaúba endocarp, was applied to the hydrodeoxygenation reaction of macaúba oil; remarkably, the degree of deoxygenation (98.4 wt.\%) for the novel catalyst measured more than 2-fold higher than that for cobalt over a commercial activated carbon [78]. In a similar approach, cobalt phosphide (CoP), supported on porous carbon synthesized from male palm flowers (PMFs) was applied to the hydrodeoxygenation of palm oil, reaching full conversion of the triacylglycerols into hydrocarbons [79]. From these studies, it may be observed that non-noble metals represent a potential catalyst for the hydrodeoxygenation of triacylglycerols to produce jet biofuels, even when such metals are supported on alternative and low-cost supports. Furthermore, the conjugation of an alkali and an acidic catalyst was proposed for effective decarboxylation and reduced coke formation, although basic catalysts were reported to exhibit low deoxygenation activity and often cause undesirable cracking thereby producing light hydrocarbon fractions [80].

\subsection{Catalytic Hydrocracking}

The hydrodeoxygenation of a given feedstock may be followed by its hydrocracking, which is a refining technology that, such as hydrodeoxygenation, falls under the general term "hydroprocessing" [81]; actually, in some cases the hydrodeoxygenation and hydrocracking may be combined into a single step [34]. However, oils and fats may possess a long carbon chain, thus the decarboxylation $\left(\mathrm{CO}_{2}\right)$ and decarbonylation $(\mathrm{CO})$ may only not be enough to reduce the carbon chain length of the feedstock to obtain hydrocarbons within the usual range of jet biofuels $\left(C_{8}-C_{16}\right)$ [21]. In this sense, aiming to fulfill the standards (e.g., cold flow properties) for alternative aviation fuels addressed by ASTM, hydrocracking may be used to break down the complex long chain of triacylglycerols into shorter structures for jet biofuel production. However, the process (catalyst and reaction conditions) must be appropriately designed to enhance the selectivity towards jet biofuel production, thereby shunning the production of light gases, naphtha and green diesel [21]. Furthermore, the hydrocracking process must be performed at high temperatures and $\mathrm{H}_{2}$ pressures to reduce coke formation by condensative chain polymerization reactions [82].

As stated previously, hydrodeoxygenation of the feedstock may generate hydrocarbons with carbon chain lengths higher than $\mathrm{C}_{16}$; therefore, the hydrocracking of the formed hydrocarbons may be necessary to obtain jet biofuels with a desirable freezing point, since short carbon chain length jet biofuels exhibit a low freezing point [47]. In this sense, bi-functional catalysts may be employed in the hydrodeoxygenation/hydrocracking of feedstocks to obtain jet biofuels. For instance, a series of bifunctional catalysts, consisting of $\mathrm{Pt}$ supported on aluminosilicate mesoporous materials, were evaluated for the production of jet biofuels; the metallic active sites performed the hydrodeoxygenation of the feedstock (biodiesel), whereas the acid active sites performed the hydrocracking reactions [83]. The authors highlighted that the acidity of the catalysts was proportional to the aluminum content in the support and, therefore, the acid strength of the catalyst support was related to its hydrocracking performance; furthermore, secondary hydrocracking reactions were observed for strong acid sites, thereby reducing the selectivity of the process in terms of jet biofuel production [83]. Similarly, a mesoporous aluminosilicate was used as support for nickel phosphate impregnation; however, in this case, the support was previously modified by zirconium ( $\mathrm{Zr}$ ), aiming to render the support mildly acidic and conducive to cracking of the reactants [84]. The novel catalyst was employed in the hydrodeoxygenation/hydrocracking of jatropha oil to obtain jet biofuels, highlighting excellent deoxidation, aromatization and cracking properties [84].

In another approach, a microporous aluminosilicate material was prepared to support $\mathrm{Ni}$ and Mo metals, and then used in the hydrocracking of waste cooking oil to obtain jet 
biofuels [85]. The catalyst exhibited high acidity and hydrothermal stability; moreover, it revealed an ability to enhance the selective cracking of waste cooking oil in jet biofuel production (compared to a mesoporous aluminosilicate material with weaker acidity, or even to the pure microporous aluminosilicate material with high acidity) [85].

\subsection{Catalytic Hydroisomerization}

The next step of converting the feedstock into jet biofuel may be its hydroisomerization, which, in turn, may be performed simultaneously with hydrocracking. The hydrocracking always follows hydroisomerization; in this sense, initially the hydroisomerization of paraffins takes place, followed by their hydrocracking, since monobranched paraffins are less susceptible to cracking than multibranched paraffins [86]. Aiming to fulfill the standards for alternative aviation fuels addressed by ASTM (e.g., cold flow properties), hydroisomerization converts straight-chain hydrocarbons into branched hydrocarbons [34]. As a matter of fact, following hydrodeoxygenation of the feedstock, the obtained hydrocarbons stream may present high paraffin content, thus it may be necessary to perform the subsequent hydroisomerization to provide branched alkanes with lower freezing points [41]. In addition, the aromatic content in jet biofuels may prove imperative for the ignition characteristics (e.g., derived cetane number) since such compounds are stable due to their unique bonding in the benzene ring [47].

Typically, in isomerization reactions, normal paraffins are dehydrogenated on the metallic sites of the catalyst, and the obtained olefins react on the acidic sites of the catalyst to form carbenium ions; then, the protonated species undergo subsequent dehydrogenation and skeletal rearrangement into iso-carbenium ions, which will be rearranged into branched (mono, di and tri) carbenium ions on acidic sites of the catalyst $[29,86,87]$. Finally, the branched carbenium ions are deprotonated on the metallic sites of the catalyst to form the corresponding iso-paraffins [29,86,87] (see Figure 4). To convert feedstocks into jet biofuels in a single-step process, bifunctional catalysts may be used. Within this process, metallic sites are required for (de)hydrogenation, and acidic sites are required for isomerization/cracking $[29,86,87]$, thus an optimum balance between the metal and acid content of the catalyst is imperative for achieving ideal catalytic characteristics for jet biofuel production [88,89] (e.g., a saturation of double bonds, decarboxylation, decarbonylation, isomerization and selective cracking without coke formation). The activity of metallic sites should be dominant over activity of the acidic sites. Specifically, the acidcatalyzed isomerization and cracking reactions should be slower (rate determining), thus mitigating over-cracking and catalyst deactivation through coke formation, as illustrated in Figure 5 [90].<smiles>[R4]CCC([R4])C</smiles>

(1)

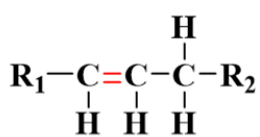<smiles>[R4]C([2H])[CH][CH][Z8]([H])([H])[H]</smiles><smiles>[GeH3]</smiles><smiles>[R4]C=C[CH+][R1]</smiles>

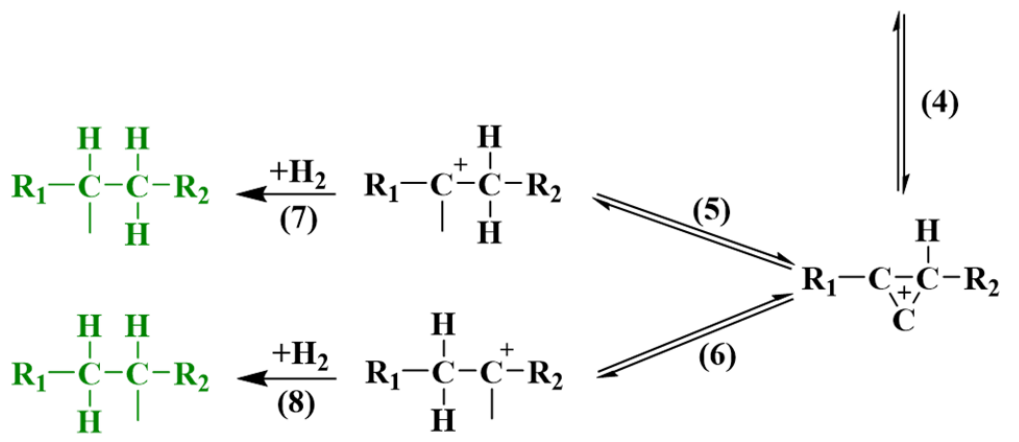

Figure 4. Hydroisomerization of normal paraffin. The (de)hydrogenation process in steps (1), (3), (7), and (8) occur at the metallic sites, while the carbenium rearrangement process in steps (2), (4), (5), and (6) occur at the acidic sites. 

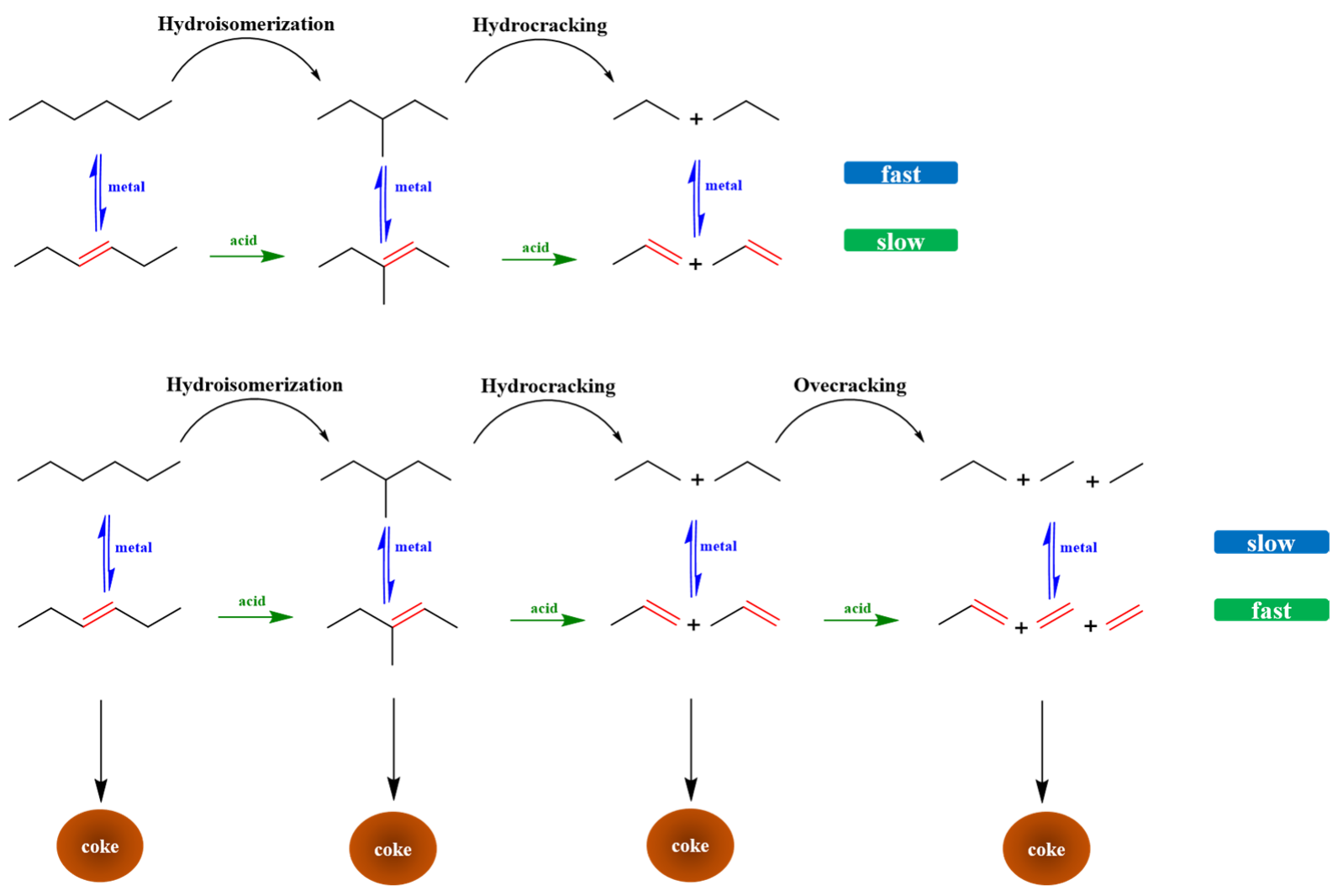

Figure 5. Reaction pathways of bifunctional catalyst for single-step conversion of feedstock into jet biofuel. Adapted from [90].

Bifunctional catalysts were also further employed for the modification of triacylglycerols to obtain jet biofuels. In this sense, hydrocracking and hydroisomerization processes may be combined into a single-step process when bifunctional catalysts are employed, thus reducing overall production costs. As reported above, bifunctional catalysts are designed to possess metallic sites for (de)hydrogenation and acidic sites for isomerization and cracking $[29,86,87]$. For example, jatropha oil was hydrodeoxygenated to obtain green diesel range hydrocarbons, which were later hydrocracked and hydroisomerized to produce jet biofuel range hydrocarbons [91]. In that study, a series of Pt-supported catalysts, using different acidic supports such as HY zeolite and amorphous silica-alumina, were employed as bifunctional catalysts for the hydrocracking and hydroisomerization of green diesel [91]. Among other important features for this process, the authors evaluated the influence of metal-acid balance and acidity of the supports; as a result, the HY zeolite-supported catalyst with the highest $\mathrm{SiO}_{2} / \mathrm{Al}_{2} \mathrm{O}_{3}$ ratio exhibited the highest activity in hydrocracking and hydroisomerization reactions, due to the well-dispersed Pt particles, large amount of Brønsted acid sites, and a proper balance between metallic and acidic sites [91]. Of particular interest, the process leads to the production of jet biofuels composed of high-branched isomers, thereby resulting in good cold flow properties (freezing point $=-47^{\circ} \mathrm{C}$ ) [91].

In another approach, jet biofuel production from technical grade coconut oil was catalyzed by sulfided $\mathrm{NiMo} / \mathrm{Al}_{2} \mathrm{O}_{3}$ catalyst, resulting in paraffins [92]. Two strategies were selected for holding the catalyst in the sulfide-state: $\mathrm{H}_{2} \mathrm{~S}$ containing hydrogen gas and a liquid sulfidation agent (dimethyl-disulfide or DMS, for short) [92]. The jet biofuel obtained from DMS-sulfided catalyst exhibited a sulfur content at least three-fold higher than that obtained from a $\mathrm{H}_{2} \mathrm{~S}$-sulfided catalyst $\left(2 \mathrm{mg} / \mathrm{kg}\right.$ for $\mathrm{H}_{2} \mathrm{~S}$ and $7-9 \mathrm{mg} / \mathrm{kg}$ for DMS) [92]. According to the authors, the produced jet biofuel exhibited excellent oxidation stability, since they were free of aromatics and olefins; however, the freezing point of the jet biofuels was higher than the ASTM Jet A-1 specification $\left(-47^{\circ} \mathrm{C}\right)$, either for the DMS-sulfided catalyst $\left(-8^{\circ} \mathrm{C}\right)$ or for the $\mathrm{H}_{2} \mathrm{~S}$-sulfided catalyst $\left(-11^{\circ} \mathrm{C}\right)$ [92]. Hence, the 
authors performed the paraffin isomerization over a Pt/SAPO (silicoaluminophosphate)11 catalyst, aiming to decrease the freezing point of the jet biofuel; as a result, a lower freezing point $\left(-45^{\circ} \mathrm{C}\right)$ was achieved from the paraffins produced using the $\mathrm{H}_{2} \mathrm{~S}$-sulfided $\mathrm{NiMo} / \mathrm{Al}_{2} \mathrm{O}_{3}$, which contained a lower sulfur content [92]. In a similar study, waste cooking oil was hydrodeoxygenated over pre-sulfided $\mathrm{NiMo} / \gamma-\mathrm{Al}_{2} \mathrm{O}_{3}$ and $\mathrm{Pd} / \mathrm{C}$ to obtain straight alkanes; among these two catalysts, the performance under milder reaction conditions of $\mathrm{Pd} / \mathrm{C}$ proved better than that of $\mathrm{NiMo} / \gamma-\mathrm{Al}_{2} \mathrm{O}_{3}$ [93]. In another study, the same group performed hydrocracking and hydroisomerization of the previously produced straight alkanes, using NiAg/SAPO-11 as the catalyst [94]. The addition of copper ( $\mathrm{Cu}$ ) may change the electronic interaction of nickel in Ni/SAPO-11 catalysts, thereby helping in suppressing the Ni/SAPO-11 cracking activity [95]. Based on this, the authors suggested silver (Ag) utilization, since $\mathrm{Cu}$ and Ag are congeners, in the Ni/SAPO-11 catalyst, to evaluate its performance in hydrocracking/isomerization reactions [94]. The authors noted that the thus obtained catalyst exhibited excellent isomerization and medium cracking capabilities, which were even better than those for the Pd/C catalysts [94].

In a similar study, NiMo was supported on SAPO-11 and then used as a catalyst in the hydrocracking and hydroisomerization of $\mathrm{C}_{15}-\mathrm{C}_{18}$ alkanes from the hydrodeoxygenation of castor oil. In this study, different $\mathrm{Si} / \mathrm{Al}$ molar ratio SAPO-11 catalysts were evaluated in the hydroisomerization of the alkanes [96]. Accordingly, the catalyst sample with moderate acidic strength exhibited the highest conversion (97.2 mol.\%) and jet biofuel selectivity (81.6 mol.\%) [96]. Furthermore, the authors mentioned that increasing temperatures yielded positive effects on the isomerization of alkanes, especially for long-chain alkanes; however, high temperatures may also have led to more intense cracking, increasing the formation of light products, and thus decreasing the overall selectivity of the process towards jet biofuel production [96]. Similarly, alkanes in the green diesel range, derived from the hydrodeoxygenation of palm oil, were further hydrotreated through isomerization and cracking over the NiAg/SAPO-11 catalyst to obtain hydrocarbons in the jet biofuel range [97]. Moreover, the authors highlighted the influence of increasing temperatures in the cracking of hydrocarbons [97].

In a fascinating study, the simultaneous hydrodeoxygenation, hydrocracking and hydroisomerization of palm kernel oil and palm olein (or their respective hydrolysates) were performed in a single step to obtain jet biofuels and other hydrocarbons [98]. In that study, a thermally activated beta zeolite (without the presence of noble metals) was employed as a catalyst, showing excellent performance in the hydrolyzed palm olein (>96 wt.\% of conversion into hydrocarbons). Moreover, due to a partial hydroisomerization, the formation of branched alkanes and aromatics products was observed. Overall, the obtained hydrocarbons presented low freezing temperatures (between -18 and $-30{ }^{\circ} \mathrm{C}$ ) and, therefore, the authors suggested their use, after refining, in blends with fossil jet fuels without significant losses in their cold properties [98].

\section{Hydrogen Consumption}

A high hydrogen content is typically required in the hydrotreatment of esters and fatty acids for jet biofuel production [50]. Nevertheless, especially regarding environmental and economic sustainability, high hydrogen consumption may prove a major drawback for the large-scale implementation of jet biofuels [36]. Furthermore, despite several efforts to obtain it from renewable resources, hydrogen has been mainly produced from non-renewable resources, particularly from natural gas steam reforming or from coal gasification [99-103]. Consequently, it is crucial to minimize hydrogen consumption in the HEFA pathway [36]. Nevertheless, as reported above, hydrogen plays an important role in the HEFA reactions, therefore it is imperative to use hydrogen from renewable resources and/or to look for alternatives to minimize hydrogen consumption.

It was reported that hydrogen consumption may be sensitive to reaction conditions and catalysts [36]. Thus, to minimize hydrogen consumption, a proper catalyst design is critical for producing jet biofuels using the HEFA pathway. Alkanes in the range of 
jet biofuels were obtained from jatropha oil hydrolysates and stearic acid without the addition of hydrogen, using tungsten $(\mathrm{W})$ added to $\mathrm{Pt}$ supported on titanium dioxide $\left(\mathrm{TiO}_{2}\right)$ catalyst [104]. This designed catalyst $\left(\mathrm{WOx} / \mathrm{Pt} / \mathrm{TiO}_{2}\right)$ exhibited up to 2-fold better deoxygenation performance than $\mathrm{Pt} / \mathrm{TiO}_{2}$ and even better than $\mathrm{WOx} / \mathrm{TiO}_{2}$, which exhibited almost no activity [104]. The authors attributed such an enhanced performance to the close interaction of $\mathrm{W}$ with the $\mathrm{Pt}$ nanoparticles supported on $\mathrm{TiO}_{2}$, enabling easier $\mathrm{C}-\mathrm{C}$ cleavage over the $\mathrm{Pt}$ nanoparticles; further, the strong bonding between the $\mathrm{W}$ of the catalyst and the oxygen atoms in the oil feedstocks improved the deoxygenation [104]. In another effort, hydrogen consumption was reduced by using a niobium phosphate $\left(\mathrm{NbOPO}_{4}\right)$ catalyst to produce jet biofuels from soybean oil [105]. The authors highlighted the acid and redox properties of this catalyst, which enabled simultaneous isomerization, cyclization, and dehydrogenation reactions under much milder $\mathrm{H}_{2}$ pressures (10 bar) [105]. In a similar study from the same group, a $\mathrm{NbOPO}_{4}$ catalyst was compared to zeolites (HBeta and ZSM-5), a commercial fluid catalytic cracking (FCC) catalyst, and $\mathrm{Pd} / \mathrm{C}$ to obtain jet biofuels from soybean oil [106]. In this study, differently from the previous work, the authors suggested a strategy for using $\mathrm{N}_{2}$ instead of $\mathrm{H}_{2}$, thereby enhancing the environmental and economic sustainability of the process [106]. As a result, although the $\mathrm{Pd} / \mathrm{C}$-catalyzed process led to lower oxygenate content $(1 \mathrm{wt} . \%)$, the $\mathrm{NbOPO}_{4}$-catalyzed process (14 wt.\%) produced only $9 \mathrm{wt} . \%$ of gases, while Pd/C generated $24 \mathrm{wt} . \%$ [106]. Moreover, the authors pointed out that the simultaneous deoxygenation, cracking and isomerization reactions were successfully performed over the $\mathrm{NbOPO}_{4}$ catalyst, without $\mathrm{H}_{2}$ pressure and under mild $\mathrm{N}_{2}$ pressure (10 bar) [106].

The influence of the $\mathrm{N}_{2}$ pressure on the conversion of triacylglycerols into hydrocarbons was further explored. In the deoxygenation of macaúba oil over $\mathrm{Pd} / \mathrm{C}$ catalyst, it was illustrated that the catalyst exhibited higher conversion under $\mathrm{H}_{2}$ atmosphere (85 wt.\%) than under $\mathrm{N}_{2}$ atmosphere (45 wt.\%) for the same synthesis conditions [67]. The $\mathrm{H}_{2}$ atmosphere favors the activity of the catalyst in its reduced form [67]; furthermore, the catalyst activity/stability is conserved for a longer time, due to the ability of $\mathrm{H}_{2}$ in promoting the desorption of contaminants from the catalyst surface $[107,108]$. Similarly, a conversion decrease in the deoxygenation of jatropha oil hydrolysate over the $\mathrm{WOx} / \mathrm{Pt} / \mathrm{TiO}_{2}$ catalyst under an $\mathrm{N}_{2}$ atmosphere ( $55 \mathrm{wt} . \%$ ) was observed when compared to $\mathrm{H}_{2}$ atmosphere (100 wt.\%) [104]. The authors attributed the decrease in the conversion to a catalyst deactivation caused by the adsorption of carbon and heavy organic compounds on the catalyst surface; however, very interestingly, in a $10 \% \mathrm{H}_{2} / \mathrm{N}_{2}$ atmosphere, the stability of the catalyst was maintained and a conversion of up to $90 \mathrm{wt} . \%$ was achieved for more than $20 \mathrm{~h}$ of TOS (Time-On-Stream) [104].

In another strategy to obtain jet biofuels, the hydrogen consumption from an external supply was replaced by an in situ hydrogen production. Formic acid was proposed as an outstanding alternative for the in situ hydrogen production and storage $[109,110]$. In this sense, formic acid was employed as a co-reactant and hydrogen donor to deoxygenate jatropha oil over a Pd/C catalyst [111]. Notably, in situ production of hydrogen from formic acid yielded higher oil conversions and higher hydrocarbon selectivity when compared to processes without the use of formic acid or to those that used only water; beyond that, when continuous deoxygenation of the feedstock was performed in a medium with formic acid, a high initial resistance to catalyst deactivation was observed [111]. Similarly, glycerol was considered a versatile raw material for in situ hydrogen production [112,113]. Therefore, glycerol was employed as a hydrogen donor in the deoxygenation of waste soybean oil catalyzed by a hybrid catalyst $\left(\mathrm{Pd} / \mathrm{C}\right.$ and $\left.\mathrm{NiO} / \gamma-\mathrm{Al}_{2} \mathrm{O}_{3}\right)$ to obtain jet biofuel [114]. In that study, the authors highlighted that the in situ hydrogen production from glycerol induced a positive effect on both the hydrogenation and deoxygenation of the feedstock. They also reported that using a hybrid catalyst $\left(2 \mathrm{~g} \mathrm{Pd} / \mathrm{C}\right.$ and $\left.1 \mathrm{~g} \mathrm{NiO} / \gamma-\mathrm{Al}_{2} \mathrm{O}_{3}\right)$ was better for performing the deoxygenation of the feedstock than increasing the content of Pd/C [114]. Another alternative for jet biofuel production is the in situ catalytic transfer hydrogenation using isopropanol as a hydrogen donor [114]. Despite the large input cost associated 
with isopropanol [114], the authors previously reported that isopropanol may represent a potential hydrogen donor for the hydroprocessing of waste cooking oil to produce biofuel, reducing or eliminating the use of gaseous hydrogen from an external source [115].

\section{Enzymatic Production of Hydrocarbons}

Enzymatic biocatalysis has increasingly been recognized as an alternative to chemical catalysis, since enzymes may perform their function under much milder conditions (ambient temperature, atmospheric pressure, and physiological pH, for instance) [116,117]. Furthermore, since enzymes may exhibit high substrate specificity or product selectivity, enzymatic biocatalysis may not only allow a drastic reduction in substrate purity requirements, but also in by-product generation, thereby simplifying downstream separation processes $[118,119]$. Notwithstanding, industrial applications of enzymes are often prevented by their low long-term storage and operational stabilities, difficulty of recovery after use and, subsequently, problematic reuse of the enzymatic catalyst. Moreover, enzyme features have evolved to modify the physiological substrates under physiological conditions, while, in most cases, industry utilizes neither the physiological substrates nor the reaction conditions. Consequently, although enzymes are almost perfect physiological catalysts, before their application in industry, they usually require improvement of their features to fit those of an industrial catalyst [120,121]. Nevertheless, such drawbacks may be mitigated when appropriate enzyme engineering techniques are employed.

In this sense, through metagenomic methodologies, it is possible to access all biodiversity; even enzymes from non-cultivable and/or no longer existing microorganisms may be screened, facilitating the search for the best available enzyme for a given process [122-124]. Furthermore, direct evolution allows the mimicry of natural evolution, but in a shorter time period, aiming to improve specific features of the enzymes [124-126]. For instance, mutagenesis may alter the enzyme activity by modifying the active site or even ex novo active sites may be formed for creating enzymes with double active sites $[127,128]$. Additionally, chemical modifications may allow chimeric artificial enzymes to create specific catalytic features, enabling better control of the biocatalytic processes [129-131]. Finally, it is possible to improve activity, specificity, selectivity, stability and reduce inhibition of enzymes if a properly immobilization protocol is employed. Moreover, even enzyme purification may be coupled to enzyme immobilization and the problems regarding the reuse of cofactors may be mitigated by enzymes and cofactors co-immobilization [132-136]. Accordingly, in aiming to implement enzymes at an industrial scale, the application of combined tools of enzyme engineering has been reported [128,137].

Lipases (triacylglycerol ester hydrolases, EC.3.1.1.3) are among the most widely used enzymes for biocatalysis [138,139], as they do not require cofactors to catalyze reactions [140]. They also exhibit high activity and are quite stable under a wide range of operational conditions, for example, aqueous, anhydrous, and neo-media (ionic liquids, supercritical fluids or deep eutectic solvents) [141-144]. Furthermore, lipases hold low specificity, being able to recognize very different substrates from physiological ones (triacylglycerols) [145]. Higher conversions into hydrocarbons were reported for the HEFA pathway when feedstocks (primarily oils) are converted into free fatty acids before treatment under $\mathrm{H}_{2}$ pressure for jet biofuel production $[67,98]$. In this sense, since the biological function of lipases is to hydrolyze triacylglycerols [146], such catalysts were employed in the hydrolysis of oils in several applications [147-152], which would be further processed in the presence of $\mathrm{H}_{2}$ pressure to obtain jet biofuels.

Furthermore, lipases may be used in vitro to catalyze the esterification of free fatty acids or the transesterification of acylglycerols with short-chain alcohols and, thus, lipases were extensively employed for enzymatic production of biodiesel [153-158], which could be further hydroprocessed for the production of drop-in jet biofuels [68]. However, the implementation of lipases for the production of biodiesel may pose some problems. The first problem is the enzyme specificity, which in some instances represents a key feature to select a biocatalytic route $[159,160]$. Recently, several papers have attempted to enlarge 
the range of substrates recognized by an enzyme [161] and, in this approach, to bear a valuable enzyme for reactions involving very different substrates. As oils are heterogeneous substrates composed of several different fatty acids that form tri-, di- or monoacylglycerols, some of them may be unideal substrates or even lipase inhibitors. With regards to this, several lipases are recommended for both oil hydrolysis and biodiesel production [162-165]. One of the advantages of lipases is the possibility of simultaneously performing esterification/transesterification reactions, thus making the previous treatment of acid oils unnecessary [166-168]. Likely, the best lipase for one process is not the best for another one [162]. Other problems are related to the production of by-products (water for esterification and glycerol for transesterification). Glycerol may act as a substrate of the enzyme, producing a decrease in the overall yield of fatty acid esters.

Moreover, glycerol may accumulate in the enzyme biocatalysts particles, inducing enzyme inactivation/inhibition [169-171]. Using very hydrophobic supports or ultrasound treatments may decrease the negative effect of glycerol [171-173]. An alternative to avoid these problems is the strategy of hydroesterification: the oils are hydrolyzed, the glycerol is eliminated, and the lipases are utilized for the esterification of the free fatty acids [174-177]. This eliminates the methanol/ethanol competition with glycerol, but water may still form a phase in the enzyme environment, causing enzyme inhibition/inactivation. The solutions are similar to those used to avoid glycerol layer formation [178-186].

There have been a number of discussions regarding the use of immobilized or nonimmobilized lipases for biodiesel production. As reported above, enzyme immobilization may improve enzyme features, but presents an additional cost to a process in which the economic balance is critical. Therefore, some companies have launched liquid lipase formulations recommended for enzymatic biodiesel production [158]. However, several studies show how the immobilization of these enzymes, launched to be used in free form, may further improve their features [186-192]. In this regard, enzyme immobilization is justified not only to facilitate the recovery and reuse of the enzyme but also to improve the enzyme features significantly. For example, recent studies reported how the immobilization of a classical lipase (that from Thermomyces lanuginosus) yields a biocatalyst that showed similar results to alkaline catalysts used in biodiesel production [193-195].

Apart from the feedstock pre-treatment and/or biodiesel production, enzymes may perform the main reactions of the HEFA pathway (hydrogenation, decarboxylation, decarbonylation, cracking and isomerization). For instance, fatty acid decarboxylases were employed in vitro for the decarboxylation of free fatty acids to obtain olefins [196-200], and fatty acid photodecarboxylases were also employed in the production of hydrocarbons [201,202]. Decarboxylases (formally carboxy-lyases, EC 4.1.1) are carbon-carbon lyases that catalyze the decarboxylation of organic compounds in the presence of a pyridoxal phosphate or a pyruvate cofactor. For example, fatty acid decarboxylases catalyze the oxidative decarboxylation of free fatty acids into hydrocarbons in a single step [203] (see Figure 6). Furthermore, the oxidative decarboxylation of free fatty acids may be performed in the presence of $\mathrm{O}_{2}$ and expensive electron-donating cofactors- $\mathrm{NAD}(\mathrm{P}) \mathrm{H}-$ or even in the presence of $\mathrm{H}_{2} \mathrm{O}_{2}$ as a redox partner; however, although $\mathrm{H}_{2} \mathrm{O}_{2}$ may bear some advantages (with water and easy to handle in large-scale applications) when compared to $\mathrm{O}_{2}$ [203], it should be considered that $\mathrm{H}_{2} \mathrm{O}_{2}$ may present a problem for the stability of involved enzymes [204]. It has even been reported that the enzymatic oxidative decarboxylation of free fatty acids using $\mathrm{H}_{2} \mathrm{O}_{2}$ as the oxidant resulted in significantly reduced catalytic activities and even protein precipitation under high $\mathrm{H}_{2} \mathrm{O}_{2}$ concentration $(>400 \mathrm{~mm})$ [205].

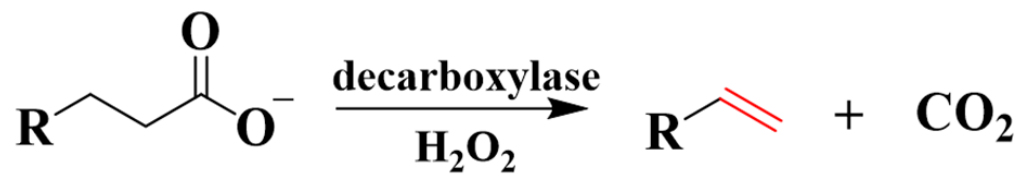

Figure 6. Enzymatic fatty acid decarboxylation. 
Another enzyme used for this purpose is the fatty acid photodecarboxylase (fatty acid carboxy-lyases, EC 4.1.1.106). They are algal photoenzymes that catalyze the decarboxylation of free fatty acids to olefins in response to blue light; in the presence of blue photons, such enzymes are able to generate fatty acid decarboxylation through electron abstraction from the fatty acid by the photoexcited flavin adenine dinucleotide (FAD) cofactor [206].

Cascade reactions were employed in many instances, involving several enzymes, since they permit complex transformations by associating several substrate modifications [207-210]. For example, a lipase was employed for the hydrolysis of triacylglycerols and a decarboxylase was employed for the subsequent decarboxylation of free fatty acids aiming to result in olefins [211,212]; thus, both lipase and decarboxylase are exposed to $\mathrm{H}_{2} \mathrm{O}_{2}$, which may present a problem for enzyme stability as reported above [204]. In another very interesting example, a multienzyme cascade system was employed for the one-pot production of $\alpha$-olefins without exogenous $\mathrm{H}_{2} \mathrm{O}_{2}$ addition, aiming to mitigate the deleterious effects of $\mathrm{H}_{2} \mathrm{O}_{2}$ on the stability of the enzyme [213]. In this system, a lipase performed hydrolysis of triacyclglycerols to form free fatty acids and glycerol. Then, an alditol oxidase was applied to oxidize the released glycerin and produce in situ two equivalents of $\mathrm{H}_{2} \mathrm{O}_{2}$ (one equivalent of $\mathrm{H}_{2} \mathrm{O}_{2}$ was employed the exogenous addition of glycerol), which was utilized by decarboxylase to decarboxylate the free fatty acids (Figure 7) [213]. This one-pot biocatalytic system achieved a $68.5 \mathrm{wt}$ \% of olefin [213].

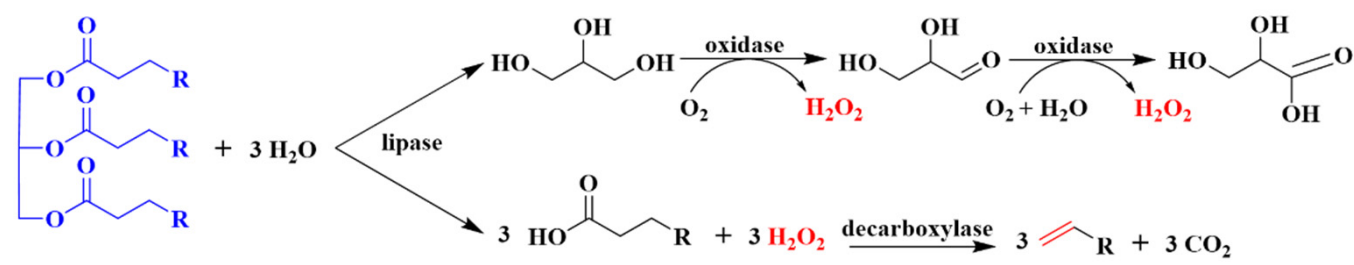

Figure 7. One-pot enzymatic production of hydrocarbons (adapted from [213]). Exogenous addition of glycerol may be employed to solve the shortage of one equivalent of $\mathrm{H}_{2} \mathrm{O}_{2}$.

To the best of the authors' efforts, up to date, it was not possible to find in the literature any peer-reviewed work on the production of jet biofuels via enzymatic HEFA (or similar) pathway; as stated above, it is possible to find reports on the production of hydrocarbons from esters and fatty acids via enzymatic biocatalysis, but none of them goes further on the characterization of the product as a jet biofuel. This may be related to the products' properties, intermediate products (e.g., $\alpha$-olefins) but not final jet biofuels. Nevertheless, the utilization of multienzymes systems was reported as a strategy to fully modify a substrate to obtain the desired product [164,214]; therefore, the utilization of such systems may provide an alternative method for the conversion of esters and free fatty acids to hydrocarbons that hold properties according to ASTM specifications.

\section{Techno-Economic Analysis}

The technological and economic feasibility of producing jet biofuels by hydroprocessing of esters and fatty acids were previously reported. For example, in 2013, it was estimated that the baseline cost for HEFA fuel production ranged between US\$1.01 and US\$ $1.16 \mathrm{~L}^{-1}$, with feedstock representing the most significant portion of the fuel cost [215]. In 2015, the ASTM-standardized pathways for the production of jet biofuels were evaluated from an economic perspective [42]. As a result, the HEFA pathway was considered the most feasible alternative; however, it was not expected to reach price parity with jet fuel in the short term [42]. In fact, it was later reported that the HEFA pathway, as with any other pathway, would not be profitable in the absence of government incentives [216]. The project medium Net Present Value (NPV) for all pathways is below zero, thereby suggesting government policy support for financial viability [217]. Furthermore, production cost estimates are higher for non-HEFA jet biofuels due to higher expenses for feedstock and capital expenditure components [218]. Notably, although triacylglycerol-based materials 
are potentially more expensive than lignocellulosic-based materials, the HEFA pathway remains quite a competitive technology since the fuel yield (86-91\%) is higher than that for lignocellulosic-based technologies (9-23\%); and, the minimum fuel selling price is lower (US\$ $1.2 \mathrm{~L}^{-1}$ ) [219,220]. Overall, the ASTM-standardized pathways for the production of jet biofuels are still far from being competitive with their fossil counterparts; however, the costs may be mitigated by the carbon market. In this scenario, the production of jet biofuel via the HEFA pathway using waste cooking oil as feedstock bears the lowest mitigation cost [221].

\section{Conclusions}

Under environmental, economic and social perspectives, the quest for sustainable development has undoubtedly represented one of the major challenges of academia, industry, and society overall. Concerning environmental sustainability, the implementation of biofuels is an imperative requirement for the reduction of $\mathrm{CO}_{2}$ emissions, among other advantages. Within this scope, biofuels bear the potential to mitigate the carbon footprint of the aviation sector and to diversify the energy matrix and, therefore, impulse the transition of an economy based on fossil fuels to that based on biofuels. The catalytic hydroprocessing of esters and fatty acids (HEFA) illustrates the most mature technology for the industrial production of jet biofuels. Notwithstanding all advantages of the HEFA pathway to obtain jet biofuels, according to this disclosure, the design of the catalyst remains a great challenge. In fact, since a variety of substrates may be used as feedstocks, producing catalysts capable of performing all reactions necessary to obtain jet biofuel within ASTM specifications may be an algorithm of trial and error. Fortunately, bifunctional catalysts (acidic and metallic sites) were successfully employed to obtain jet biofuels under specification, and some approaches have even performed it in a one-pot cascade reaction. Furthermore, although there were improvements in catalyst design and in the endogenous production of $\mathrm{H}_{2}$, the high exogenous consumption of fossil-derived $\mathrm{H}_{2}$ still presents a bottleneck for the production of jet biofuels. Therefore, the processing of esters and fatty acids by biocatalysts may provide an interesting alternative for the production of hydrocarbons under mild reaction conditions (ambient temperature and atmospheric pressure). However, it is still necessary to further improve the engineering of such biocatalysts to obtain hydrocarbons within ASTM specifications, at a high efficiency and product selectivity and in an economically viable process.

Author Contributions: R.R.C.M., I.A.d.S. and M.R.A.A. performed the first bibliographic search and wrote the first draft; C.L.C.J., F.M.T.d.L., R.F.-L. and R.S.V. conceptualized, wrote the first draft and edited the final version of the paper. All authors have read and agreed to the published version of the manuscript.

Funding: The authors wish to acknowledge the financial support from PROCAD/CAPES (88881.068439/2014-01). R.F.-L. gratefully recognizes the support from the Ministerio de Ciencia e Innovación from Spanish Government (project number CTQ2017-86170-R) and CSIC for the project AEP045.

Data Availability Statement: Not applicable.

Acknowledgments: R.R.C.M. thanks Programa de Formação de Recursos Humanos-Agência Nacional de Petróleo Gás Natural e Biocombustíveis/Financiadora de Estudos e Projetos (PRH 31.1ANP/Finep). I.A.d.S. thanks Coordenação de Aperfeiçoamento de Pessoal de Nível Superior Brasil (CAPES)_Finance Code 001.

Conflicts of Interest: The authors declare no conflict of interest.

\section{References}

1. International Energy Agency (IEA). Global Energy Review 2020; IEA: Paris, France, 2020.

2. International Energy Agency (IEA). World Energy Outlook 2020; IEA: Paris, France, 2020.

3. International Renewable Energy Agency (IRENA). Renewable Capacity Statistics 2021; IRENA: Abu Dabi, United Arab Emirates, 2021.

4. International Renewable Energy Agency (IRENA). Global Energy Transformation; IRENA: Abu Dabi, United Arab Emirates, 2018. 
5. International Renewable Energy Agency (IRENA). World Energy Transitions Outlook: $1.5^{\circ} \mathrm{C}$ Pathway; IRENA: Abu Dabi, United Arab Emirates, 2021.

6. Energy Information Administration (EIA). International Energy Outlook 2019 with Projections to 2050; EIA: Washington, DC, USA, 2019.

7. International Energy Agency (IEA). Tracking Transport 2020; IEA: Paris, France, 2020.

8. International Energy Agency (IEA). Aviation; IEA: Paris, France, 2020.

9. International Civil Aviation Organization (ICAO). 2019 Environmental Report; ICAO: Montreal, QC, Canada, 2020.

10. CORSIA and COVID-19. Available online: https://www.icao.int/environmental-protection/CORSIA/Pages/CORSIA-andCovid-19.aspx (accessed on 21 April 2021).

11. Staples, M.D.; Malina, R.; Suresh, P.; Hileman, J.I.; Barrett, S.R.H. Aviation $\mathrm{CO}_{2}$ Emissions Reductions from the Use of Alternative Jet Fuels. Energy Policy 2018, 114, 342-354. [CrossRef]

12. Alic, J.A. Biofuel Battles: Politics, Policy, and the Pentagon. Energy Res. Soc. Sci. 2015, 10, 10-18. [CrossRef]

13. Deane, P.; Gallachóir, B.Ó.; Shea, R.O. Biofuels for Aviation. In Europe's Energy Transition—Insights for Policy Making; Elsevier: Amsterdam, The Netherlands, 2017; pp. 79-88, ISBN 978-0-12-809806-6.

14. Deane, J.P.; Pye, S. Europe's Ambition for Biofuels in Aviation-A Strategic Review of Challenges and Opportunities. Energy Strategy Rev. 2018, 20, 1-5. [CrossRef]

15. De Souza, L.M.; Mendes, P.A.S.; Aranda, D.A.G. Assessing the Current Scenario of the Brazilian Biojet Market. Renew. Sustain. Energy Rev. 2018, 98, 426-438. [CrossRef]

16. Chao, H.; Agusdinata, D.B.; DeLaurentis, D.A. The Potential Impacts of Emissions Trading Scheme and Biofuel Options to Carbon Emissions of U.S. Airlines. Energy Policy 2019, 134, 110993. [CrossRef]

17. International Energy Agency (IEA). Transport Biofuels; IEA: Paris, France, 2020.

18. Demirbas, A. Progress and Recent Trends in Biofuels. Prog. Energy Combust. Sci. 2007, 33, 1-18. [CrossRef]

19. Connelly, E.B.; Colosi, L.M.; Clarens, A.F.; Lambert, J.H. Risk analysis of biofuels industry for aviation with scenario-based expert elicitation: Connelly, colosi, clarens and lambert. Syst. Eng. 2015, 18, 178-191. [CrossRef]

20. Awudu, I.; Zhang, J. Uncertainties and Sustainability Concepts in Biofuel Supply Chain Management: A Review. Renew. Sustain. Energy Rev. 2012, 16, 1359-1368. [CrossRef]

21. Gutiérrez-Antonio, C.; Gómez-Castro, F.I.; de Lira-Flores, J.A.; Hernández, S. A Review on the Production Processes of Renewable Jet Fuel. Renew. Sustain. Energy Rev. 2017, 79, 709-729. [CrossRef]

22. Kandaramath Hari, T.; Yaakob, Z.; Binitha, N.N. Aviation Biofuel from Renewable Resources: Routes, Opportunities and Challenges. Renew. Sustain. Energy Rev. 2015, 42, 1234-1244. [CrossRef]

23. Doliente, S.S.; Narayan, A.; Tapia, J.F.D.; Samsatli, N.J.; Zhao, Y.; Samsatli, S. Bio-Aviation Fuel: A Comprehensive Review and Analysis of the Supply Chain Components. Front. Energy Res. 2020, 8. [CrossRef]

24. Rumizen, M. Aviation Biofuel Standards and Airworthiness Approval. In Biokerosene; Kaltschmitt, M., Neuling, U., Eds.; Springer: Berlin/Heidelberg, Germany, 2018; pp. 639-663. ISBN 978-3-662-53063-4.

25. Wang, W.-C.; Tao, L.; Markham, J.; Zhang, Y.; Tan, E.; Batan, L.; Warner, E.; Biddy, M. Review of Biojet Fuel Conversion Technologies, Technical Report TP-5100-66291, 1278318; NREL: Golden, CO, USA, 2016.

26. International Renewable Energy Agency (IRENA). Biofuels for Aviation: Technology Brief; IRENA: Abu Dabi, United Arab Emirates, 2017.

27. D02 Committee. Specification for Aviation Turbine Fuel Containing Synthesized Hydrocarbons; ASTM International: West Conshohocken, PA, USA, 2011.

28. D02 Committee. Specification for Aviation Turbine Fuels; ASTM International: West Conshohocken, PA, USA, 2018.

29. Wang, W.-C.; Tao, L. Bio-Jet Fuel Conversion Technologies. Renew. Sustain. Energy Rev. 2016, 53, 801-822. [CrossRef]

30. Karatzos, S.; van Dyk, J.S.; McMillan, J.D.; Saddler, J. Drop-in Biofuel Production via Conventional (Lipid/Fatty Acid) and Advanced (Biomass) Routes. Part I. Biofuels Bioprod. Bioref. 2017, 11, 344-362. [CrossRef]

31. Wei, H.; Liu, W.; Chen, X.; Yang, Q.; Li, J.; Chen, H. Renewable Bio-Jet Fuel Production for Aviation: A Review. Fuel 2019, 254, 115599. [CrossRef]

32. Bwapwa, J.K.; Anandraj, A.; Trois, C. Possibilities for Conversion of Microalgae Oil into Aviation Fuel: A Review. Renew. Sustain. Energy Rev. 2017, 80, 1345-1354. [CrossRef]

33. Cheng, F.; Brewer, C.E. Producing Jet Fuel from Biomass Lignin: Potential Pathways to Alkyl-Benzenes and Cycloalkanes. Renew. Sustain. Energy Rev. 2017, 72, 673-722. [CrossRef]

34. Goh, B.H.H.; Chong, C.T.; Ge, Y.; Ong, H.C.; Ng, J.-H.; Tian, B.; Ashokkumar, V.; Lim, S.; Seljak, T.; Józsa, V. Progress in Utilisation of Waste Cooking Oil for Sustainable Biodiesel and Biojet Fuel Production. Energy Convers. Manag. 2020, 223, 113296. [CrossRef]

35. Karkal, S.S.; Kudre, T.G. Valorization of Fish Discards for the Sustainable Production of Renewable Fuels. J. Clean. Prod. 2020, 275, 122985. [CrossRef]

36. Choudhary, T.V.; Phillips, C.B. Renewable Fuels via Catalytic Hydrodeoxygenation. Appl. Catal. A Gen. 2011, 397, 1-12. [CrossRef]

37. Romero-Izquierdo, A.G.; Gutiérrez-Antonio, C.; Gómez-Castro, F.I.; Hernández, S. Hydrotreating of Triglyceride Feedstock to Produce Renewable Aviation Fuel. RICE 2018, 11, 77-89. [CrossRef]

38. Khan, S.; Kay Lup, A.N.; Qureshi, K.M.; Abnisa, F.; Wan Daud, W.M.A.; Patah, M.F.A. A Review on Deoxygenation of Triglycerides for Jet Fuel Range Hydrocarbons. J. Anal. Appl. Pyrol. 2019, 140, 1-24. [CrossRef] 
39. Why, E.S.K.; Ong, H.C.; Lee, H.V.; Gan, Y.Y.; Chen, W.-H.; Chong, C.T. Renewable Aviation Fuel by Advanced Hydroprocessing of Biomass: Challenges and Perspective. Energy Convers. Manag. 2019, 199, 112015. [CrossRef]

40. Ooi, X.Y.; Gao, W.; Ong, H.C.; Lee, H.V.; Juan, J.C.; Chen, W.H.; Lee, K.T. Overview on Catalytic Deoxygenation for Biofuel Synthesis Using Metal Oxide Supported Catalysts. Renew. Sustain. Energy Rev. 2019, 112, 834-852. [CrossRef]

41. Neuling, U.; Kaltschmitt, M. Conversion routes from biomass to biokerosene. In Biokerosene; Kaltschmitt, M., Neuling, U., Eds.; Springer: Berlin/Heidelberg, Germany, 2018; pp. 435-473, ISBN 978-3-662-53063-4.

42. De Jong, S.; Hoefnagels, R.; Faaij, A.; Slade, R.; Mawhood, R.; Junginger, M. The Feasibility of Short-Term Production Strategies for Renewable Jet Fuels-A Comprehensive Techno-Economic Comparison. Biofuels Bioprod. Biorefin. 2015, 9, 778-800. [CrossRef]

43. Diederichs, G.W.; Ali Mandegari, M.; Farzad, S.; Görgens, J.F. Techno-Economic Comparison of Biojet Fuel Production from Lignocellulose, Vegetable Oil and Sugar Cane Juice. Bioresource Technol. 2016, 216, 331-339. [CrossRef] [PubMed]

44. Neuling, U.; Kaltschmitt, M. Techno-Economic and Environmental Analysis of Aviation Biofuels. Fuel Process. Technol. 2018, 171, 54-69. [CrossRef]

45. Guo, K.; Li, H.; Yu, Z. In-Situ Heavy and Extra-Heavy Oil Recovery: A Review. Fuel 2016, 185, 886-902. [CrossRef]

46. Li, Y.; Wang, Z.; Hu, Z.; Xu, B.; Li, Y.; Pu, W.; Zhao, J. A Review of in Situ Upgrading Technology for Heavy Crude Oil. Petroleum 2020, 7, 117-122. [CrossRef]

47. Yang, J.; Xin, Z.; He, Q.S.; Corscadden, K.; Niu, H. An Overview on Performance Characteristics of Bio-Jet Fuels. Fuel 2019, 237, 916-936. [CrossRef]

48. Tao, L.; Milbrandt, A.; Zhang, Y.; Wang, W.-C. Techno-Economic and Resource Analysis of Hydroprocessed Renewable Jet Fuel. Biotechnol. Biofuels 2017, 10, 261. [CrossRef]

49. De Souza, L.M.; Mendes, P.A.S.; Aranda, D.A.G. Oleaginous Feedstocks for Hydro-Processed Esters and Fatty Acids (HEFA) Biojet Production in Southeastern Brazil: A Multi-Criteria Decision Analysis. Renew. Energy 2020, 149, 1339-1351. [CrossRef]

50. Popov, S.; Kumar, S. Renewable Fuels via Catalytic Hydrodeoxygenation of Lipid-Based Feedstocks. Biofuels 2013, 4, 219-239. [CrossRef]

51. Neuling, U.; Kaltschmitt, M. Biokerosene from Vegetable Oils-Technologies and Processes. In Biokerosene; Kaltschmitt, M., Neuling, U., Eds.; Springer: Berlin/Heidelberg, Germany, 2018; pp. 475-496, ISBN 978-3-662-53063-4.

52. Arcanjo, M.R.A.; Silva, I.J.; Cavalcante, C.L.; Iglesias, J.; Morales, G.; Paniagua, M.; Melero, J.A.; Vieira, R.S. Glycerol Valorization: Conversion to Lactic Acid by Heterogeneous Catalysis and Separation by Ion Exchange Chromatography. Biofuels Bioprod. Bioref. 2020, 14, 357-370. [CrossRef]

53. Stedile, T.; Ender, L.; Meier, H.F.; Simionatto, E.L.; Wiggers, V.R. Comparison between Physical Properties and Chemical Composition of Bio-Oils Derived from Lignocellulose and Triglyceride Sources. Renew. Sustain. Energy Rev. 2015, 50, 92-108. [CrossRef]

54. Mohammad, M.; Kandaramath Hari, T.; Yaakob, Z.; Chandra Sharma, Y.; Sopian, K. Overview on the Production of Paraffin Based-Biofuels via Catalytic Hydrodeoxygenation. Renew. Sustain. Energy Rev. 2013, 22, 121-132. [CrossRef]

55. Llamas, A.; Al-Lal, A.-M.; Hernandez, M.; Lapuerta, M.; Canoira, L. Biokerosene from Babassu and Camelina Oils: Production and Properties of Their Blends with Fossil Kerosene. Energy Fuels 2012, 26, 5968-5976. [CrossRef]

56. Llamas, A.; García-Martínez, M.; Al-Lal, A.-M.; Canoira, L.; Lapuerta, M. Biokerosene from Coconut and Palm Kernel Oils: Production and Properties of Their Blends with Fossil Kerosene. Fuel 2012, 102, 483-490. [CrossRef]

57. Silva, L.N.; Cardoso, C.C.; Pasa, V.M.D. Synthesis and Characterization of Esters from Different Alcohols Using Macauba Almond Oil to Substitute Diesel Oil and Jet Fuel. Fuel 2016, 166, 453-460. [CrossRef]

58. De Oliveira, V.F.; Parente, E.J.S.; Cavalcante, C.L.; Luna, F.M.T. Short-Chain Esters Enriched Biofuel Obtained from Vegetable Oil Using Molecular Distillation. Can. J. Chem. Eng. 2018, 96, 1071-1078. [CrossRef]

59. Chandran, D. Compatibility of Diesel Engine Materials with Biodiesel Fuel. Renew. Energy 2020, 147, 89-99. [CrossRef]

60. Da Silva, J.Q.; Santos, D.Q.; Fabris, J.D.; Harter, L.V.L.; Chagas, S.P. Light Biodiesel from Macaúba and Palm Kernel: Properties of Their Blends with Fossil Kerosene in the Perspective of an Alternative Aviation Fuel. Renew. Energy 2020, 151, 426-433. [CrossRef]

61. Gosselink, R.W.; Hollak, S.A.W.; Chang, S.-W.; van Haveren, J.; de Jong, K.P.; Bitter, J.H.; van I Es, D.S. Reaction Pathways for the Deoxygenation of Vegetable Oils and Related Model Compounds. ChemSusChem 2013, 6, 1576-1594. [CrossRef] [PubMed]

62. Vonghia, E.; Boocock, D.G.B.; Konar, S.K.; Leung, A. Pathways for the Deoxygenation of Triglycerides to Aliphatic Hydrocarbons over Activated Alumina. Energy Fuels 1995, 9, 1090-1096. [CrossRef]

63. Pattanaik, B.P.; Misra, R.D. Effect of Reaction Pathway and Operating Parameters on the Deoxygenation of Vegetable Oils to Produce Diesel Range Hydrocarbon Fuels: A Review. Renew. Sustain. Energy Rev. 2017, 73, 545-557. [CrossRef]

64. Santillan-Jimenez, E.; Crocker, M. Catalytic Deoxygenation of Fatty Acids and Their Derivatives to Hydrocarbon Fuels via Decarboxylation/Decarbonylation. J. Chem. Technol. Biotechnol. 2012, 87, 1041-1050. [CrossRef]

65. Ameen, M.; Azizan, M.T.; Yusup, S.; Ramli, A.; Yasir, M. Catalytic Hydrodeoxygenation of Triglycerides: An Approach to Clean Diesel Fuel Production. Renew. Sustain. Energy Rev. 2017, 80, 1072-1088. [CrossRef]

66. Lee, S.-U.; Kim, E.S.; Kim, T.-W.; Kim, J.-R.; Jeong, K.-E.; Lee, S.; Kim, C.-U. Effect of Silica Supports on Deoxygenation of Methyl Palmitate over Mesoporous Silica-Supported Ni/Al Catalysts. J. Ind. Eng. Chem. 2020, 83, 366-374. [CrossRef]

67. Silva, L.N.; Fortes, I.C.P.; de Sousa, F.P.; Pasa, V.M.D. Biokerosene and Green Diesel from Macauba Oils via Catalytic Deoxygenation over Pd/C. Fuel 2016, 164, 329-338. [CrossRef] 
68. Araújo, P.H.M.; Maia, A.S.; Cordeiro, A.M.T.M.; Gondim, A.D.; Santos, N.A. Catalytic Deoxygenation of the Oil and Biodiesel of Licuri (Syagrus Coronata) To Obtain $n$-Alkanes with Chains in the Range of Biojet Fuels. ACS Omega 2019, 4, 15849-15855. [CrossRef]

69. Cheah, K.W.; Taylor, M.J.; Osatiashtiani, A.; Beaumont, S.K.; Nowakowski, D.J.; Yusup, S.; Bridgwater, A.V.; Kyriakou, G. Monometallic and Bimetallic Catalysts Based on $\mathrm{Pd}, \mathrm{Cu}$ and $\mathrm{Ni}$ for Hydrogen Transfer Deoxygenation of a Prototypical Fatty Acid to Diesel Range Hydrocarbons. Catal. Today 2020, 355, 882-892. [CrossRef]

70. Zhang, Z.; Wang, Q.; Chen, H.; Zhang, X. Hydroconversion of Waste Cooking Oil into Green Biofuel over Hierarchical USYSupported NiMo Catalyst: A Comparative Study of Desilication and Dealumination. Catalysts 2017, 7, 281. [CrossRef]

71. Zhang, Z.; Wang, Q.; Chen, H.; Zhang, X. Hydroconversion of Waste Cooking Oil into Bio-Jet Fuel over a Hierarchical NiMo/USY@Al-SBA-15 Zeolite. Chem. Eng. Technol. 2018, 41, 590-597. [CrossRef]

72. Mayorga, M.; Cadavid, J.; Martinez, J.; Rodriguez, L.; Trujillo, C.A.; Lopez, M.; Bonilla, J.; Lopez, C. Evaluation of Zeolite-Based Catalyst Supports for the Production of Biokerosene by Hydrotreating of Oils. Chem. Eng. Trans. 2019, 74, 13-18. [CrossRef]

73. Madsen, A.T.; Ahmed, E.H.; Christensen, C.H.; Fehrmann, R.; Riisager, A. Hydrodeoxygenation of Waste Fat for Diesel Production: Study on Model Feed with Pt/Alumina Catalyst. Fuel 2011, 90, 3433-3438. [CrossRef]

74. Rabaev, M.; Landau, M.V.; Vidruk-Nehemya, R.; Goldbourt, A.; Herskowitz, M. Improvement of Hydrothermal Stability of Pt/SAPO-11 Catalyst in Hydrodeoxygenation-Isomerization-Aromatization of Vegetable Oil. J. Catal. 2015, 332, 164-176. [CrossRef]

75. Domínguez-Barroso, M.V.; Herrera, C.; Larrubia, M.A.; Alemany, L.J. Diesel Oil-like Hydrocarbon Production from Vegetable Oil in a Single Process over Pt-Ni/Al2O3 and Pd/C Combined Catalysts. Fuel Process. Technol. 2016, 148, 110-116. [CrossRef]

76. Kim, T.-H.; Lee, K.; Kim, M.Y.; Chang, Y.K.; Choi, M. Effects of Fatty Acid Compositions on Heavy Oligomer Formation and Catalyst Deactivation during Deoxygenation of Triglycerides. ACS Sustain. Chem. Eng. 2018, 6, 17168-17177. [CrossRef]

77. Jeong, H.; Shin, M.; Jeong, B.; Jang, J.H.; Han, G.B.; Suh, Y.-W. Comparison of Activity and Stability of Supported Ni2P and Pt Catalysts in the Hydroprocessing of Palm Oil into Normal Paraffins. J. Ind. Eng. Chem. 2020, 83, 189-199. [CrossRef]

78. Moreira, J.; Rezende, D.; Pasa, V.M.D. Deoxygenation of Macauba Acid Oil over Co-Based Catalyst Supported on Activated Biochar from Macauba Endocarp: A Potential and Sustainable Route for Green Diesel and Biokerosene Production. Fuel 2020, 269, 117253. [CrossRef]

79. Kaewtrakulchai, N.; Kaewmeesri, R.; Itthibenchapong, V.; Eiad-Ua, A.; Faungnawakij, K. Palm Oil Conversion to Bio-Jet and Green Diesel Fuels over Cobalt Phosphide on Porous Carbons Derived from Palm Male Flowers. Catalysts 2020, 10, 694. [CrossRef]

80. Alsultan, G.A.; Asikin-Mijan, N.; Lee, H.V.; Albazzaz, A.S.; Taufiq-Yap, Y.H. Deoxygenation of Waste Cooking to Renewable Diesel over Walnut Shell-Derived Nanorode Activated Carbon Supported CaO- $\mathrm{La}_{2} \mathrm{O}_{3}$ Catalyst. Energy Convers. Manag. 2017, 151, 311-323. [CrossRef]

81. Speight, J.G. Hydrocracking. In The Refinery of the Future; Elsevier: Amsterdam, The Netherlands, 2020; pp. 303-342, ISBN 978-0-12-816994-0.

82. Sotelo-Boyas, R.; Trejo-Zarraga, F.; de Jesus Hernandez-Loyo, F. Hydroconversion of triglycerides into green liquid fuels. In Hydrogenation; Karam, I., Ed.; InTech: London, UK, 2012; ISBN 978-953-51-0785-9.

83. Lu, M.; Liu, X.; Li, Y.; Nie, Y.; Lu, X.; Deng, D.; Xie, Q.; Ji, J. Hydrocracking of Bio-Alkanes over Pt/Al-MCM-41 Mesoporous Molecular Sieves for Bio-Jet Fuel Production. J. Renew. Sustain. Energy 2016, 8, 053103. [CrossRef]

84. Tan, Q.; Cao, Y.; Li, J. Prepared Multifunctional Catalyst Ni2P/Zr-SBA-15 and Catalyzed Jatropha Oil to Produce Bio-Aviation Fuel. Renew. Energy 2020, 150, 370-381. [CrossRef]

85. Zhang, Z.; Wang, Q.; Zhang, X. Hydroconversion of Waste Cooking Oil into Bio-Jet Fuel over NiMo/SBUY-MCM-41. Catalysts 2019, 9, 466. [CrossRef]

86. Deldari, H. Suitable Catalysts for Hydroisomerization of Long-Chain Normal Paraffins. Appl. Catal. A Gen. 2005, 293, 1-10. [CrossRef]

87. Zhang, M.; Chen, Y.; Wang, L.; Zhang, Q.; Tsang, C.-W.; Liang, C. Shape Selectivity in Hydroisomerization of Hexadecane over Pt Supported on 10-Ring Zeolites: ZSM-22, ZSM-23, ZSM-35, and ZSM-48. Ind. Eng. Chem. Res. 2016, 55, 6069-6078. [CrossRef]

88. Guisnet, M. “Ideal” Bifunctional Catalysis over Pt-Acid Zeolites. Catal. Today 2013, 218-219, 123-134. [CrossRef]

89. Regali, F.; Liotta, L.F.; Venezia, A.M.; Montes, V.; Boutonnet, M.; Järås, S. Effect of Metal Loading on Activity, Selectivity and Deactivation Behavior of Pd/Silica-Alumina Catalysts in the Hydroconversion of n-Hexadecane. Catal. Today 2014, $223,87-96$. [CrossRef]

90. Lee, K.; Lee, M.-E.; Kim, J.-K.; Shin, B.; Choi, M. Single-Step Hydroconversion of Triglycerides into Biojet Fuel Using CO-Tolerant PtRe Catalyst Supported on USY. J. Catal. 2019, 379, 180-190. [CrossRef]

91. Hengsawad, T.; Srimingkwanchai, C.; Butnark, S.; Resasco, D.E.; Jongpatiwut, S. Effect of Metal-Acid Balance on Hydroprocessed Renewable Jet Fuel Synthesis from Hydrocracking and Hydroisomerization of Biohydrogenated Diesel over Pt-Supported Catalysts. Ind. Eng. Chem. Res. 2018, 57, 1429-1440. [CrossRef]

92. Eller, Z.; Varga, Z.; Hancsók, J. Advanced Production Process of Jet Fuel Components from Technical Grade Coconut Oil with Special Hydrocracking. Fuel 2016, 182, 713-720. [CrossRef]

93. Chen, R.-X.; Wang, W.-C. The Production of Renewable Aviation Fuel from Waste Cooking Oil. Part I: Bio-Alkane Conversion through Hydro-Processing of Oil. Renew. Energy 2019, 135, 819-835. [CrossRef] 
94. Chen, Y.-K.; Hsieh, C.-H.; Wang, W.-C. The Production of Renewable Aviation Fuel from Waste Cooking Oil. Part II: Catalytic Hydro-Cracking/Isomerization of Hydro-Processed Alkanes into Jet Fuel Range Products. Renew. Energy 2020, 157, 731-740. [CrossRef]

95. Yang, Z.; Liu, Y.; Liu, D.; Meng, X.; Liu, C. Hydroisomerization of n -Octane over Bimetallic Ni-Cu/SAPO-11 Catalysts. Appl. Catal. A Gen. 2017, 543, 274-282. [CrossRef]

96. Xing, G.; Liu, S.; Guan, Q.; Li, W. Investigation on Hydroisomerization and Hydrocracking of C15-C18 n-Alkanes Utilizing a Hollow Tubular Ni-Mo/SAPO-11 Catalyst with High Selectivity of Jet Fuel. Catal. Today 2019, 330, 109-116. [CrossRef]

97. Lin, C.-H.; Chen, Y.-K.; Wang, W.-C. The Production of Bio-Jet Fuel from Palm Oil Derived Alkanes. Fuel 2020, $260,116345$. [CrossRef]

98. Sousa, F.P.; Silva, L.N.; de Rezende, D.B.; de Oliveira, L.C.A.; Pasa, V.M.D. Simultaneous Deoxygenation, Cracking and Isomerization of Palm Kernel Oil and Palm Olein over Beta Zeolite to Produce Biogasoline, Green Diesel and Biojet-Fuel. Fuel 2018, 223, 149-156. [CrossRef]

99. Acar, C.; Dincer, I. Comparative Assessment of Hydrogen Production Methods from Renewable and Non-Renewable Sources. Int. J. Hydrog. Energy 2014, 39, 1-12. [CrossRef]

100. Hosseini, S.E.; Wahid, M.A. Hydrogen Production from Renewable and Sustainable Energy Resources: Promising Green Energy Carrier for Clean Development. Renew. Sustain. Energy Rev. 2016, 57, 850-866. [CrossRef]

101. Martinez-Burgos, W.J.; de Souza Candeo, E.; Pedroni Medeiros, A.B.; Cesar de Carvalho, J.; Oliveira de Andrade Tanobe, V.; Soccol, C.R.; Sydney, E.B. Hydrogen: Current Advances and Patented Technologies of Its Renewable Production. J. Clean. Prod. 2021, 286, 124970. [CrossRef]

102. Dahiya, S.; Chatterjee, S.; Sarkar, O.; Mohan, S.V. Renewable Hydrogen Production by Dark-Fermentation: Current Status, Challenges and Perspectives. Bioresource Technol. 2021, 321, 124354. [CrossRef] [PubMed]

103. Hydrogen-Analysis. Available online: https://www.iea.org/reports/hydrogen (accessed on 2 April 2021).

104. Choi, I.-H.; Lee, J.-S.; Kim, C.-U.; Kim, T.-W.; Lee, K.-Y.; Hwang, K.-R. Production of Bio-Jet Fuel Range Alkanes from Catalytic Deoxygenation of Jatropha Fatty Acids on a $\mathrm{WOx} / \mathrm{Pt} / \mathrm{TiO}_{2}$ Catalyst. Fuel 2018, 215, 675-685. [CrossRef]

105. Scaldaferri, C.A.; Pasa, V.M.D. Production of Jet Fuel and Green Diesel Range Biohydrocarbons by Hydroprocessing of Soybean Oil over Niobium Phosphate Catalyst. Fuel 2019, 245, 458-466. [CrossRef]

106. Scaldaferri, C.A.; Pasa, V.M.D. Hydrogen-Free Process to Convert Lipids into Bio-Jet Fuel and Green Diesel over Niobium Phosphate Catalyst in One-Step. Chem. Eng. J. 2019, 370, 98-109. [CrossRef]

107. Mäki-Arvela, P.; Kubickova, I.; Snåre, M.; Eränen, K.; Murzin, D.Y. Catalytic Deoxygenation of Fatty Acids and Their Derivatives. Energy Fuels 2007, 21, 30-41. [CrossRef]

108. Immer, J.G.; Kelly, M.J.; Lamb, H.H. Catalytic Reaction Pathways in Liquid-Phase Deoxygenation of C18 Free Fatty Acids. Appl. Catal. A Gen. 2010, 375, 134-139. [CrossRef]

109. Wang, X.; Meng, Q.; Gao, L.; Jin, Z.; Ge, J.; Liu, C.; Xing, W. Recent Progress in Hydrogen Production from Formic Acid Decomposition. Int. J. Hydrog. Energy 2018, 43, 7055-7071. [CrossRef]

110. Navlani-García, M.; Mori, K.; Salinas-Torres, D.; Kuwahara, Y.; Yamashita, H. New Approaches Toward the Hydrogen Production From Formic Acid Dehydrogenation Over Pd-Based Heterogeneous Catalysts. Front. Mater. 2019, 6, 44. [CrossRef]

111. Hwang, K.-R.; Choi, I.-H.; Choi, H.-Y.; Han, J.-S.; Lee, K.-H.; Lee, J.-S. Bio Fuel Production from Crude Jatropha Oil; Addition Effect of Formic Acid as an in-Situ Hydrogen Source. Fuel 2016, 174, 107-113. [CrossRef]

112. Lin, Y.-C. Catalytic Valorization of Glycerol to Hydrogen and Syngas. Int. J. Hydrog. Energy 2013, 38, 2678-2700. [CrossRef]

113. Schwengber, C.A.; Alves, H.J.; Schaffner, R.A.; da Silva, F.A.; Sequinel, R.; Bach, V.R.; Ferracin, R.J. Overview of Glycerol Reforming for Hydrogen Production. Renew. Sustain. Energy Rev. 2016, 58, 259-266. [CrossRef]

114. Choi, I.-H.; Hwang, K.-R.; Choi, H.-Y.; Lee, J.-S. Catalytic Deoxygenation of Waste Soybean Oil over Hybrid Catalyst for Production of Bio-Jet Fuel: In Situ Supply of Hydrogen by Aqueous-Phase Reforming (APR) of Glycerol. Res. Chem. Intermed. 2018, 44, 3713-3722. [CrossRef]

115. Asiedu, A.; Barbera, E.; Naurzaliyev, R.; Bertucco, A.; Kumar, S. Waste Cooking Oil to Jet-Diesel Fuel Range Using 2-Propanol via Catalytic Transfer Hydrogenation Reactions. Biofuels 2019, 12, 723-736. [CrossRef]

116. Sheldon, R.A.; Brady, D. Broadening the Scope of Biocatalysis in Sustainable Organic Synthesis. ChemSusChem 2019, 12, $2859-2881$. [CrossRef] [PubMed]

117. Bornscheuer, U.T.; Huisman, G.W.; Kazlauskas, R.J.; Lutz, S.; Moore, J.C.; Robins, K. Engineering the Third Wave of Biocatalysis. Nature 2012, 485, 185-194. [CrossRef] [PubMed]

118. Choi, J.-M.; Han, S.-S.; Kim, H.-S. Industrial Applications of Enzyme Biocatalysis: Current Status and Future Aspects. Biotechnol. Adv. 2015, 33, 1443-1454. [CrossRef] [PubMed]

119. Chapman, J.; Ismail, A.; Dinu, C. Industrial Applications of Enzymes: Recent Advances, Techniques, and Outlooks. Catalysts 2018, 8, 238. [CrossRef]

120. Schmid, A.; Dordick, J.S.; Hauer, B.; Kiener, A.; Wubbolts, M.; Witholt, B. Industrial Biocatalysis Today and Tomorrow. Nature 2001, 409, 258-268. [CrossRef]

121. Singh, R.; Tiwari, M.; Singh, R.; Lee, J.-K. From Protein Engineering to Immobilization: Promising Strategies for the Upgrade of Industrial Enzymes. Int. J. Mol. Sci. 2013, 14, 1232-1277. [CrossRef] 
122. Ferrer, M.; Martinezabarca, F.; Golyshin, P. Mining Genomes and 'Metagenomes' for Novel Catalysts. Curr. Opin. Biotechnol. 2005, 16, 588-593. [CrossRef]

123. Ferrer, M.; Beloqui, A.; Timmis, K.N.; Golyshin, P.N. Metagenomics for Mining New Genetic Resources of Microbial Communities. J. Mol. Microbiol. Biotechnol. 2009, 16, 109-123. [CrossRef] [PubMed]

124. Ferrer, M.; Martínez-Martínez, M.; Bargiela, R.; Streit, W.R.; Golyshina, O.V.; Golyshin, P.N. Estimating the Success of Enzyme Bioprospecting through Metagenomics: Current Status and Future Trends: Enzyme Bioprospecting by Metagenomics. Microb. Biotechnol. 2016, 9, 22-34. [CrossRef] [PubMed]

125. Ren, C.; Wen, X.; Mencius, J.; Quan, S. Selection and Screening Strategies in Directed Evolution to Improve Protein Stability Bioresources Bioprocess. 2019, 6, 53. [CrossRef]

126. Romero, P.A.; Arnold, F.H. Exploring Protein Fitness Landscapes by Directed Evolution. Nat. Rev. Mol. Cell Biol. 2009, 10, 866-876. [CrossRef]

127. Chin, J. Developing Artificial Hydrolytic Metalloenzymes by a Unified Mechanistic Approach. Acc. Chem. Res. 1991, 24, 145-152. [CrossRef]

128. Santiago, G.; Martínez-Martínez, M.; Alonso, S.; Bargiela, R.; Coscolín, C.; Golyshin, P.N.; Guallar, V.; Ferrer, M. Rational Engineering of Multiple Active Sites in an Ester Hydrolase. Biochemistry 2018, 57, 2245-2255. [CrossRef] [PubMed]

129. Spicer, C.D.; Davis, B.G. Selective Chemical Protein Modification. Nat. Commun. 2014, 5, 4740. [CrossRef]

130. Boutureira, O.; Bernardes, G.J.L. Advances in Chemical Protein Modification. Chem. Rev. 2015, 115, 2174-2195. [CrossRef]

131. Sakamoto, S.; Hamachi, I. Recent Progress in Chemical Modification of Proteins. Anal. Sci. 2019, 35, 5-27. [CrossRef]

132. Mateo, C.; Palomo, J.M.; Fernandez-Lorente, G.; Guisan, J.M.; Fernandez-Lafuente, R. Improvement of Enzyme Activity, Stability and Selectivity via Immobilization Techniques. Enzyme Microb. Technol. 2007, 40, 1451-1463. [CrossRef]

133. Brady, D.; Jordaan, J. Advances in Enzyme Immobilisation. Biotechnol. Lett. 2009, 31, 1639-1650. [CrossRef] [PubMed]

134. Garcia-Galan, C.; Berenguer-Murcia, Á.; Fernandez-Lafuente, R.; Rodrigues, R.C. Potential of Different Enzyme Immobilization Strategies to Improve Enzyme Performance. Adv. Synth. Catal. 2011, 353, 2885-2904. [CrossRef]

135. Rodrigues, R.C.; Ortiz, C.; Berenguer-Murcia, Á.; Torres, R.; Fernández-Lafuente, R. Modifying Enzyme Activity and Selectivity by Immobilization. Chem. Soc. Rev. 2013, 42, 6290-6307. [CrossRef] [PubMed]

136. Barbosa, O.; Ortiz, C.; Berenguer-Murcia, Á.; Torres, R.; Rodrigues, R.C.; Fernandez-Lafuente, R. Strategies for the One-Step Immobilization-Purification of Enzymes as Industrial Biocatalysts. Biotechnol. Adv. 2015, 33, 435-456. [CrossRef]

137. Alonso, S.; Santiago, G.; Cea-Rama, I.; Fernandez-Lopez, L.; Coscolín, C.; Modregger, J.; Ressmann, A.K.; Martínez-Martínez, M.; Marrero, H.; Bargiela, R.; et al. Genetically Engineered Proteins with Two Active Sites for Enhanced Biocatalysis and Synergistic Chemo- and Biocatalysis. Nat. Catal. 2020, 3, 319-328. [CrossRef]

138. Ortiz, C.; Ferreira, M.L.; Barbosa, O.; dos Santos, J.C.S.; Rodrigues, R.C.; Berenguer-Murcia, Á.; Briand, L.E.; Fernandez-Lafuente, R. Novozym 435: The "Perfect" Lipase Immobilized Biocatalyst? Catal. Sci. Technol. 2019, 9, 2380-2420. [CrossRef]

139. Monteiro, R.R.C.; Virgen-Ortiz, J.J.; Berenguer-Murcia, Á.; da Rocha, T.N.; dos Santos, J.C.S.; Alcántara, A.R.; Fernandez-Lafuente, R. Biotechnological Relevance of the Lipase A from Candida antarctica. Catal. Today 2021, 362, 141-154. [CrossRef]

140. Wang, Y.; San, K.-Y.; Bennett, G.N. Cofactor Engineering for Advancing Chemical Biotechnology. Curr. Opin. Biotechnol. 2013, 24, 994-999. [CrossRef]

141. Kumar, A.; Dhar, K.; Kanwar, S.S.; Arora, P.K. Lipase Catalysis in Organic Solvents: Advantages and Applications. Biol. Proc. Online 2016, 18, 2. [CrossRef]

142. Elgharbawy, A.A.; Riyadi, F.A.; Alam, M.Z.; Moniruzzaman, M. Ionic Liquids as a Potential Solvent for Lipase-Catalysed Reactions: A Review. J. Mol. Liq. 2018, 251, 150-166. [CrossRef]

143. Sheldon, R.A. Biocatalysis and Biomass Conversion in Alternative Reaction Media. Chem. Eur. J. 2016, 22, 12984-12999. [CrossRef]

144. Matsuda, T. Recent Progress in Biocatalysis Using Supercritical Carbon Dioxide. J. Biosci. Bioeng. 2013, 115, 233-241. [CrossRef] [PubMed]

145. Dwivedee, B.P.; Soni, S.; Sharma, M.; Bhaumik, J.; Laha, J.K.; Banerjee, U.C. Promiscuity of Lipase-Catalyzed Reactions for Organic Synthesis: A Recent Update. ChemistrySelect 2018, 3, 2441-2466. [CrossRef]

146. Schmid, R.D.; Verger, R. Lipases: Interfacial Enzymes with Attractive Applications. Angew. Chem. Int. Ed. 1998, 37, 1608-1633. [CrossRef]

147. Jaeger, K. Microbial Lipases Form Versatile Tools for Biotechnology. Trends Biotechnol. 1998, 16, 396-403. [CrossRef]

148. Murty, V.R.; Bhat, J.; Muniswaran, P.K.A. Hydrolysis of Oils by Using Immobilized Lipase Enzyme: A Review. Biotechnol. Bioprocess Eng. 2002, 7, 57-66. [CrossRef]

149. Rodrigues, R.C.; Fernandez-Lafuente, R. Lipase from Rhizomucor miehei as a Biocatalyst in Fats and Oils Modification. J. Mol. Catal. B Enzymat. 2010, 66, 15-32. [CrossRef]

150. Fernandez-Lafuente, R. Lipase from Thermomyces lanuginosus: Uses and Prospects as an Industrial Biocatalyst. J. Mol. Catal. B Enzymat. 2010, 62, 197-212. [CrossRef]

151. Goswami, D.; Basu, J.K.; De, S. Lipase Applications in Oil Hydrolysis with a Case Study on Castor Oil: A Review. Crit. Rev. Biotechnol. 2013, 33, 81-96. [CrossRef]

152. López-Fernández, J.; Benaiges, M.D.; Valero, F. Rhizopus Oryzae Lipase, a Promising Industrial Enzyme: Biochemical Characteristics, Production and Biocatalytic Applications. Catalysts 2020, 10, 1277. [CrossRef] 
153. Fukuda, H.; Kondo, A.; Noda, H. Biodiesel Fuel Production by Transesterification of Oils. J. Biosci. Bioeng. 2001, 92, 405-416. [CrossRef]

154. Shimada, Y.; Watanabe, Y.; Sugihara, A.; Tominaga, Y. Enzymatic Alcoholysis for Biodiesel Fuel Production and Application of the Reaction to Oil Processing. J. Mol. Catal. B Enzymat. 2002, 17, 133-142. [CrossRef]

155. Fjerbaek, L.; Christensen, K.V.; Norddahl, B. A Review of the Current State of Biodiesel Production Using Enzymatic Transesterification. Biotechnol. Bioeng. 2009, 102, 1298-1315. [CrossRef] [PubMed]

156. Moazeni, F.; Chen, Y.-C.; Zhang, G. Enzymatic Transesterification for Biodiesel Production from Used Cooking Oil, a Review. J. Clean. Prod. 2019, 216, 117-128. [CrossRef]

157. Almeida, F.L.C.; Travália, B.M.; Gonçalves, I.S.; Forte, M.B.S. Biodiesel Production by Lipase-catalyzed Reactions: Bibliometric Analysis and Study of Trends. Biofuels Bioprod. Bioref. 2021, bbb.2183. [CrossRef]

158. Monteiro, R.R.C.; Arana-Peña, S.; da Rocha, T.N.; Miranda, L.P.; Berenguer-Murcia, Á.; Tardioli, P.W.; dos Santos, J.C.S.; FernandezLafuente, R. Liquid Lipase Preparations Designed for Industrial Production of Biodiesel. Is It Really an Optimal Solution? Renew. Energy 2021, 164, 1566-1587. [CrossRef]

159. Ghanem, A.; Aboul-Enein, H.Y. Lipase-Mediated Chiral Resolution of Racemates in Organic Solvents. Tetrahedron Asymmetry 2004, 15, 3331-3351. [CrossRef]

160. José, C.; Toledo, M.V.; Briand, L.E. Enzymatic Kinetic Resolution of Racemic Ibuprofen: Past, Present and Future. Crit. Rev. Biotechnol. 2016, 36, 891-903. [CrossRef]

161. Roda, S.; Fernandez-Lopez, L.; Cañadas, R.; Santiago, G.; Ferrer, M.; Guallar, V. Computationally Driven Rational Design of Substrate Promiscuity on Serine Ester Hydrolases. ACS Catal. 2021, 11, 3590-3601. [CrossRef]

162. Arana-Peña, S.; Carballares, D.; Berenguer-Murcia, Á.; Alcántara, A.R.; Rodrigues, R.C.; Fernandez-Lafuente, R. One Pot Use of Combilipases for Full Modification of Oils and Fats: Multifunctional and Heterogeneous Substrates. Catalysts 2020, 10, 605. [CrossRef]

163. Bilal, M.; Iqbal, H.M.N. Tailoring Multipurpose Biocatalysts via Protein Engineering Approaches: A Review. Catal. Lett. 2019, 149, 2204-2217. [CrossRef]

164. Ren, S.; Li, C.; Jiao, X.; Jia, S.; Jiang, Y.; Bilal, M.; Cui, J. Recent Progress in Multienzymes Co-Immobilization and Multienzyme System Applications. Chem. Eng. J. 2019, 373, 1254-1278. [CrossRef]

165. Sheldon, R. CLEAs, Combi-CLEAs and 'Smart' Magnetic CLEAs: Biocatalysis in a Bio-Based Economy. Catalysts 2019,9 , 261. [CrossRef]

166. Aguieiras, E.C.G.; Cavalcanti-Oliveira, E.D.; de Castro, A.M.; Langone, M.A.P.; Freire, D.M.G. Biodiesel Production from Acrocomia aculeata Acid Oil by (Enzyme/Enzyme) Hydroesterification Process: Use of Vegetable Lipase and Fermented Solid as Low-Cost Biocatalysts. Fuel 2014, 135, 315-321. [CrossRef]

167. Muanruksa, P.; Dujjanutat, P.; Kaewkannetra, P. Entrapping Immobilisation of Lipase on Biocomposite Hydrogels toward for Biodiesel Production from Waste Frying Acid Oil. Catalysts 2020, 10, 834. [CrossRef]

168. Pedro, K.C.N.R.; Ferreira, I.E.P.; Henriques, C.A.; Langone, M.A.P. Enzymatic Fatty Acid Ethyl Esters Synthesis Using Acid Soybean Oil and Liquid Lipase Formulation. Chem. Eng. Commun. 2020, 207, 43-55. [CrossRef]

169. Marty, A.; Dossat, V.; Condoret, J.S. Continuous Operation of Lipase-Catalyzed Reactions in Nonaqueous Solvents: Influence of the Production of Hydrophilic Compounds. Biotechnol. Bioeng. 1997, 56, 232-237. [CrossRef]

170. Dossat, V.; Combes, D.; Marty, A. Continuous Enzymatic Transesterification of High Oleic Sunflower Oil in a Packed Bed Reactor: Influence of the Glycerol Production. Enzyme Microb. Technol. 1999, 25, 194-200. [CrossRef]

171. Séverac, E.; Galy, O.; Turon, F.; Pantel, C.A.; Condoret, J.-S.; Monsan, P.; Marty, A. Selection of CalB Immobilization Method to Be Used in Continuous Oil Transesterification: Analysis of the Economical Impact. Enzyme Microb. Technol. 2011, 48, 61-70. [CrossRef] [PubMed]

172. Poppe, J.K.; Matte, C.R.; Fernandez-Lafuente, R.; Rodrigues, R.C.; Ayub, M.A.Z. Transesterification of Waste Frying Oil and Soybean Oil by Combi-Lipases Under Ultrasound-Assisted Reactions. Appl. Biochem. Biotechnol. 2018, 186, 576-589. [CrossRef] [PubMed]

173. Santos, F.F.P.; Rodrigues, S.; Fernandes, F.A.N. Optimization of the Production of Biodiesel from Soybean Oil by Ultrasound Assisted Methanolysis. Fuel Process. Technol. 2009, 90, 312-316. [CrossRef]

174. De Sousa, J.S.; d'Avila Cavalcanti-Oliveira, E.; Aranda, D.A.G.; Freire, D.M.G. Application of Lipase from the Physic Nut (Jatropha curcas L.) to a New Hybrid (Enzyme/Chemical) Hydroesterification Process for Biodiesel Production. J. Mol. Catal. B Enzymat. 2010, 65, 133-137. [CrossRef]

175. D'Avila Cavalcanti-Oliveira, E.; da Silva, P.R.; Ramos, A.P.; Aranda, D.A.G.; Freire, D.M.G. Study of Soybean Oil Hydrolysis Catalyzed by Thermomyces lanuginosus Lipase and Its Application to Biodiesel Production via Hydroesterification. Enzyme Res. 2011, 2011, 1-9. [CrossRef] [PubMed]

176. Costa, M.J.; Silva, M.R.L.; Ferreira, E.E.A.; Carvalho, A.K.F.; Basso, R.C.; Pereira, E.B.; de Castro, H.F.; Mendes, A.A.; Hirata, D.B. Enzymatic Biodiesel Production by Hydroesterification Using Waste Cooking Oil as Feedstock. Chem. Eng. Process.-Process Intensificat. 2020, 157, 108131. [CrossRef]

177. Wancura, J.H.C.; Fantinel, A.L.; Ugalde, G.A.; Donato, F.F.; Vladimir de Oliveira, J.; Tres, M.V.; Jahn, S.L. Semi-Continuous Production of Biodiesel on Pilot Scale via Enzymatic Hydroesterification of Waste Material: Process and Economics Considerations. J. Clean. Prod. 2021, 285, 124838. [CrossRef] 
178. Graebin, N.G.; Martins, A.B.; Lorenzoni, A.S.G.; Garcia-Galan, C.; Fernandez-Lafuente, R.; Ayub, M.A.Z.; Rodrigues, R.C. Immobilization of Lipase B from Candida Antarctica on Porous Styrene-Divinylbenzene Beads Improves Butyl Acetate Synthesis. Biotechnol. Prog. 2012, 28, 406-412. [CrossRef] [PubMed]

179. Martins, A.B.; Friedrich, J.L.R.; Cavalheiro, J.C.; Garcia-Galan, C.; Barbosa, O.; Ayub, M.A.Z.; Fernandez-Lafuente, R.; Rodrigues, R.C. Improved Production of Butyl Butyrate with Lipase from Thermomyces lanuginosus Immobilized on Styrene-Divinylbenzene Beads. Bioresource Technol. 2013, 134, 417-422. [CrossRef] [PubMed]

180. Martins, A.B.; Schein, M.F.; Friedrich, J.L.R.; Fernandez-Lafuente, R.; Ayub, M.A.Z.; Rodrigues, R.C. Ultrasound-Assisted Butyl Acetate Synthesis Catalyzed by Novozym 435: Enhanced Activity and Operational Stability. Ultrason. Sonochem. 2013, 20, 1155-1160. [CrossRef] [PubMed]

181. Poppe, J.K.; Garcia-Galan, C.; Matte, C.R.; Fernandez-Lafuente, R.; Rodrigues, R.C.; Ayub, M.A.Z. Optimization of Synthesis of Fatty Acid Methyl Esters Catalyzed by Lipase B from Candida antarctica Immobilized on Hydrophobic Supports. J. Mol. Catal. B Enzymat. 2013, 94, 51-56. [CrossRef]

182. Friedrich, J.L.R.; Peña, F.P.; Garcia-Galan, C.; Fernandez-Lafuente, R.; Ayub, M.A.Z.; Rodrigues, R.C. Effect of Immobilization Protocol on Optimal Conditions of Ethyl Butyrate Synthesis Catalyzed by Lipase B from Candida antarctica: Ethyl Butyrate Synthesis Catalyzed by CALB. J. Chem. Technol. Biotechnol. 2013, 88, 1089-1095. [CrossRef]

183. Martins, A.B.; Friedrich, J.L.R.; Rodrigues, R.C.; Garcia-Galan, C.; Fernandez-Lafuente, R.; Ayub, M.A.Z. Optimized Butyl Butyrate Synthesis Catalyzed by Thermomyces lanuginosus Lipase. Biotechnol. Prog. 2013, 29, 1416-1421. [CrossRef] [PubMed]

184. Alves, J.; Garcia-Galan, C.; Schein, M.; Silva, A.; Barbosa, O.; Ayub, M.; Fernandez-Lafuente, R.; Rodrigues, R. Combined Effects of Ultrasound and Immobilization Protocol on Butyl Acetate Synthesis Catalyzed by CALB. Molecules 2014, 19, 9562-9576. [CrossRef] [PubMed]

185. Fallavena, L.P.; Antunes, F.H.F.; Alves, J.S.; Paludo, N.; Ayub, M.A.Z.; Fernandez-Lafuente, R.; Rodrigues, R.C. Ultrasound Technology and Molecular Sieves Improve the Thermodynamically Controlled Esterification of Butyric Acid Mediated by Immobilized Lipase from Rhizomucor miehei. RSC Adv. 2014, 4, 8675. [CrossRef]

186. Paludo, N.; Alves, J.S.; Altmann, C.; Ayub, M.A.Z.; Fernandez-Lafuente, R.; Rodrigues, R.C. The Combined Use of Ultrasound and Molecular Sieves Improves the Synthesis of Ethyl Butyrate Catalyzed by Immobilized Thermomyces lanuginosus Lipase. Ultrason. Sonochem. 2015, 22, 89-94. [CrossRef]

187. Arana-Peña, S.; Lokha, Y.; Fernández-Lafuente, R. Immobilization of Eversa Lipase on Octyl Agarose Beads and Preliminary Characterization of Stability and Activity Features. Catalysts 2018, 8, 511. [CrossRef]

188. Thangaraj, B.; Solomon, P.R. Immobilization of Lipases-A Review. Part I: Enzyme Immobilization. ChemBioEng Rev. 2019, 6, 157-166. [CrossRef]

189. Facin, B.R.; Melchiors, M.S.; Valério, A.; Oliveira, J.V.; de Oliveira, D. Driving Immobilized Lipases as Biocatalysts: 10 Years State of the Art and Future Prospects. Ind. Eng. Chem. Res. 2019, 58, 5358-5378. [CrossRef]

190. Miranda, L.P.; Guimarães, J.R.; Giordano, R.C.; Fernandez-Lafuente, R.; Tardioli, P.W. Composites of Crosslinked Aggregates of Eversa ${ }^{\circledR}$ Transform and Magnetic Nanoparticles. Performance in the Ethanolysis of Soybean Oil. Catalysts 2020, $10,817$. [CrossRef]

191. Martínez-Sanchez, J.A.; Arana-Peña, S.; Carballares, D.; Yates, M.; Otero, C.; Fernandez-Lafuente, R. Immobilized Biocatalysts of Eversa ${ }^{\circledR}$ Transform 2.0 and Lipase from Thermomyces lanuginosus: Comparison of Some Properties and Performance in Biodiesel Production. Catalysts 2020, 10, 738. [CrossRef]

192. Guimarães, J.R.; Miranda, L.P.; Fernandez-Lafuente, R.; Tardioli, P.W. Immobilization of Eversa ${ }^{\circledR}$ Transform via CLEA Technology Converts It in a Suitable Biocatalyst for Biolubricant Production Using Waste Cooking Oil. Molecules 2021, 26, 193. [CrossRef]

193. Tacias-Pascacio, V.G.; Virgen-Ortíz, J.J.; Jiménez-Pérez, M.; Yates, M.; Torrestiana-Sanchez, B.; Rosales-Quintero, A.; FernandezLafuente, R. Evaluation of Different Lipase Biocatalysts in the Production of Biodiesel from Used Cooking Oil: Critical Role of the Immobilization Support. Fuel 2017, 200, 1-10. [CrossRef]

194. Tacias-Pascacio, V.G.; Torrestiana-Sánchez, B.; Dal Magro, L.; Virgen-Ortíz, J.J.; Suárez-Ruíz, F.J.; Rodrigues, R.C.; FernandezLafuente, R. Comparison of Acid, Basic and Enzymatic Catalysis on the Production of Biodiesel after RSM Optimization. Renew. Energy 2019, 135, 1-9. [CrossRef]

195. Ching-Velasquez, J.; Fernández-Lafuente, R.; Rodrigues, R.C.; Plata, V.; Rosales-Quintero, A.; Torrestiana-Sánchez, B.; TaciasPascacio, V.G. Production and Characterization of Biodiesel from Oil of Fish Waste by Enzymatic Catalysis. Renew. Energy 2020, 153, 1346-1354. [CrossRef]

196. Rude, M.A.; Baron, T.S.; Brubaker, S.; Alibhai, M.; Del Cardayre, S.B.; Schirmer, A. Terminal Olefin (1-Alkene) Biosynthesis by a Novel P450 Fatty Acid Decarboxylase from Jeotgalicoccus Species. Appl. Environ. Microbiol. 2011, 77, 1718-1727. [CrossRef] [PubMed]

197. Liu, Y.; Wang, C.; Yan, J.; Zhang, W.; Guan, W.; Lu, X.; Li, S. Hydrogen Peroxide-Independent Production of $\alpha$-Alkenes by OleTJE P450 Fatty Acid Decarboxylase. Biotechnol. Biofuels 2014, 7, 28. [CrossRef] [PubMed]

198. Xu, H.; Ning, L.; Yang, W.; Fang, B.; Wang, C.; Wang, Y.; Xu, J.; Collin, S.; Laeuffer, F.; Fourage, L.; et al. In Vitro Oxidative Decarboxylation of Free Fatty Acids to Terminal Alkenes by Two New P450 Peroxygenases. Biotechnol. Biofuels 2017, 10, 208. [CrossRef] [PubMed]

199. Wang, J.; Yu, H.; Zhu, K. Employing Metabolic Engineered Lipolytic Microbial Platform for 1-Alkene One-Step Conversion. Bioresource Technol. 2018, 263, 172-179. [CrossRef] [PubMed] 
200. Jiang, Y.; Li, Z.; Wang, C.; Zhou, Y.J.; Xu, H.; Li, S. Biochemical Characterization of Three New $\alpha$-Olefin-Producing P450 Fatty Acid Decarboxylases with a Halophilic Property. Biotechnol. Biofuels 2019, 12, 79. [CrossRef] [PubMed]

201. Bruder, S.; Moldenhauer, E.J.; Lemke, R.D.; Ledesma-Amaro, R.; Kabisch, J. Drop-in Biofuel Production Using Fatty Acid Photodecarboxylase from Chlorella variabilis in the Oleaginous Yeast Yarrowia Lipolytica. Biotechnol. Biofuels 2019, $12,202$. [CrossRef] [PubMed]

202. Karava, M.; Gockel, P.; Kabisch, J. Bacillus Subtilis Spore Surface Display of Photodecarboxylase for the Transformation of Lipids to Hydrocarbons. Sustain. Energy Fuels 2021, 5, 1727-1733. [CrossRef]

203. Wang, S.; Jiang, S.; Chen, H.; Bai, W.-J.; Wang, X. Directed Evolution of a Hydroxylase into a Decarboxylase for Synthesis of 1-Alkenes from Fatty Acids. ACS Catal. 2020, 10, 14375-14379. [CrossRef]

204. Hernandez, K.; Berenguer-Murcia, A.; Rodrigues, C.R.; Fernandez-Lafuente, R. Hydrogen Peroxide in Biocatalysis. A Dangerous Liaison. COC 2012, 16, 2652-2672. [CrossRef]

205. Dennig, A.; Kuhn, M.; Tassoti, S.; Thiessenhusen, A.; Gilch, S.; Bülter, T.; Haas, T.; Hall, M.; Faber, K. Oxidative Decarboxylation of Short-Chain Fatty Acids to 1-Alkenes. Angew. Chem. Int. Ed. 2015, 54, 8819-8822. [CrossRef] [PubMed]

206. Sorigué, D.; Légeret, B.; Cuiné, S.; Blangy, S.; Moulin, S.; Billon, E.; Richaud, P.; Brugière, S.; Couté, Y.; Nurizzo, D.; et al. An Algal Photoenzyme Converts Fatty Acids to Hydrocarbons. Science 2017, 357, 903-907. [CrossRef] [PubMed]

207. Schmidt, S.; Castiglione, K.; Kourist, R. Overcoming the Incompatibility Challenge in Chemoenzymatic and Multi-Catalytic Cascade Reactions. Chem. Eur. J. 2018, 24, 1755-1768. [CrossRef] [PubMed]

208. Zhang, Y.; Hess, H. Toward Rational Design of High-Efficiency Enzyme Cascades. ACS Catal. 2017, 7, 6018-6027. [CrossRef]

209. Hwang, E.T.; Lee, S. Multienzymatic Cascade Reactions via Enzyme Complex by Immobilization. ACS Catal. 2019,9 , 4402-4425. [CrossRef]

210. Walsh, C.T.; Moore, B.S. Enzymatic Cascade Reactions in Biosynthesis. Angew. Chem. Int. Ed. 2019, 58, 6846-6879. [CrossRef]

211. Yan, J.; Liu, Y.; Wang, C.; Han, B.; Li, S. Assembly of Lipase and P450 Fatty Acid Decarboxylase to Constitute a Novel Biosynthetic Pathway for Production of 1-Alkenes from Renewable Triacylglycerols and Oils. Biotechnol. Biofuels 2015, 8, 34. [CrossRef]

212. Li, F.; Yang, K.; Xu, Y.; Qiao, Y.; Yan, Y.; Yan, J. A Genetically-Encoded Synthetic Self-Assembled Multienzyme Complex of Lipase and P450 Fatty Acid Decarboxylase for Efficient Bioproduction of Fatty Alkenes. Bioresour. Technol. 2019, 272, 451-457. [CrossRef]

213. Jiang, Y.; Li, Z.; Zheng, S.; Xu, H.; Zhou, Y.J.; Gao, Z.; Meng, C.; Li, S. Establishing an Enzyme Cascade for One-Pot Production of $\alpha$-Olefins from Low-Cost Triglycerides and Oils without Exogenous $\mathrm{H}_{2} \mathrm{O}_{2}$ Addition. Biotechnol. Biofuels 2020, 13, 52. [CrossRef] [PubMed]

214. Arana-Peña, S.; Carballares, D.; Morellon-Sterlling, R.; Berenguer-Murcia, Á.; Alcántara, A.R.; Rodrigues, R.C.; FernandezLafuente, R. Enzyme Co-Immobilization: Always the Biocatalyst Designers' Choice ... or Not? Biotechnol. Adv. 2020, 107584. [CrossRef] [PubMed]

215. Pearlson, M.; Wollersheim, C.; Hileman, J. A Techno-Economic Review of Hydroprocessed Renewable Esters and Fatty Acids for Jet Fuel Production. Biofuels Bioprod. Bioref. 2013, 7, 89-96. [CrossRef]

216. Bann, S.J.; Malina, R.; Staples, M.D.; Suresh, P.; Pearlson, M.; Tyner, W.E.; Hileman, J.I.; Barrett, S. The Costs of Production of Alternative Jet Fuel: A Harmonized Stochastic Assessment. Bioresour. Technol. 2017, 227, 179-187. [CrossRef]

217. Wang, Z.J.; Staples, M.D.; Tyner, W.E.; Zhao, X.; Malina, R.; Olcay, H.; Allroggen, F.; Barrett, S.R.H. Quantitative Policy Analysis for Sustainable Aviation Fuel Production Technologies. Front. Energy Res. 2021, 9, 751722. [CrossRef]

218. Witcover, J.; Williams, R.B. Comparison of "Advanced" Biofuel Cost Estimates: Trends during Rollout of Low Carbon Fuel Policies. Transp. Res. Pt. D Transp. Environ. 2020, 79, 102211. [CrossRef]

219. Tanzil, A.H.; Brandt, K.; Wolcott, M.; Zhang, X.; Garcia-Perez, M. Strategic Assessment of Sustainable Aviation Fuel Production Technologies: Yield Improvement and Cost Reduction Opportunities. Biomass Bioenergy 2021, 145, 105942. [CrossRef]

220. Ng, K.S.; Farooq, D.; Yang, A. Global Biorenewable Development Strategies for Sustainable Aviation Fuel Production. Renew. Sustain. Energy Rev. 2021, 150, 111502. [CrossRef]

221. Capaz, R.S.; Guida, E.; Seabra, J.E.A.; Osseweijer, P.; Posada, J.A. Mitigating Carbon Emissions through Sustainable Aviation Fuels: Costs and Potential. Biofuels Bioprod. Bioref. 2021, 15, 502-524. [CrossRef] 